\title{
20. PETROGRAPHICAL AND GEOCHEMICAL STUDY OF THE LOW TEMPERATURE SUBMARINE ALTERATION OF BASALT FROM HOLE 396B, LEG 46
}

\author{
J. Honnorez, J. K. Bohlke, and B. M. Honnorez-Guerstein, Rosenstiel School of Marine and Atmospheric Science, \\ University of Miami, Miami, Florida
}

\section{INTRODUCTION}

We conducted a combined mineralogical, petrological, and geochemical study of altered basaltic rock samples of the upper oceanic crust from Hole 396B IPOD Leg 46. The hole was drilled on the west flank of the Mid-Atlantic Ridge, in anomaly 5 at about $23^{\circ} \mathrm{N}$. The site is located in a sediment pond at a water depth of 4450 meters; 205 meters of pillow lavas intercalated with indurated ooze and one exceptionally thick lava unit (sill or flow?) were drilled (Figure 1). The estimated age of the oldest overlying sediment, which belongs to the Discoaster exilis Zone, is about 13 m.y. or middle Miocene.

Let us follow the evolution of a given basaltic lava body or unit, from the time it is emplaced by a submarine eruption, on or close to the sea floor of the ridge, to the time

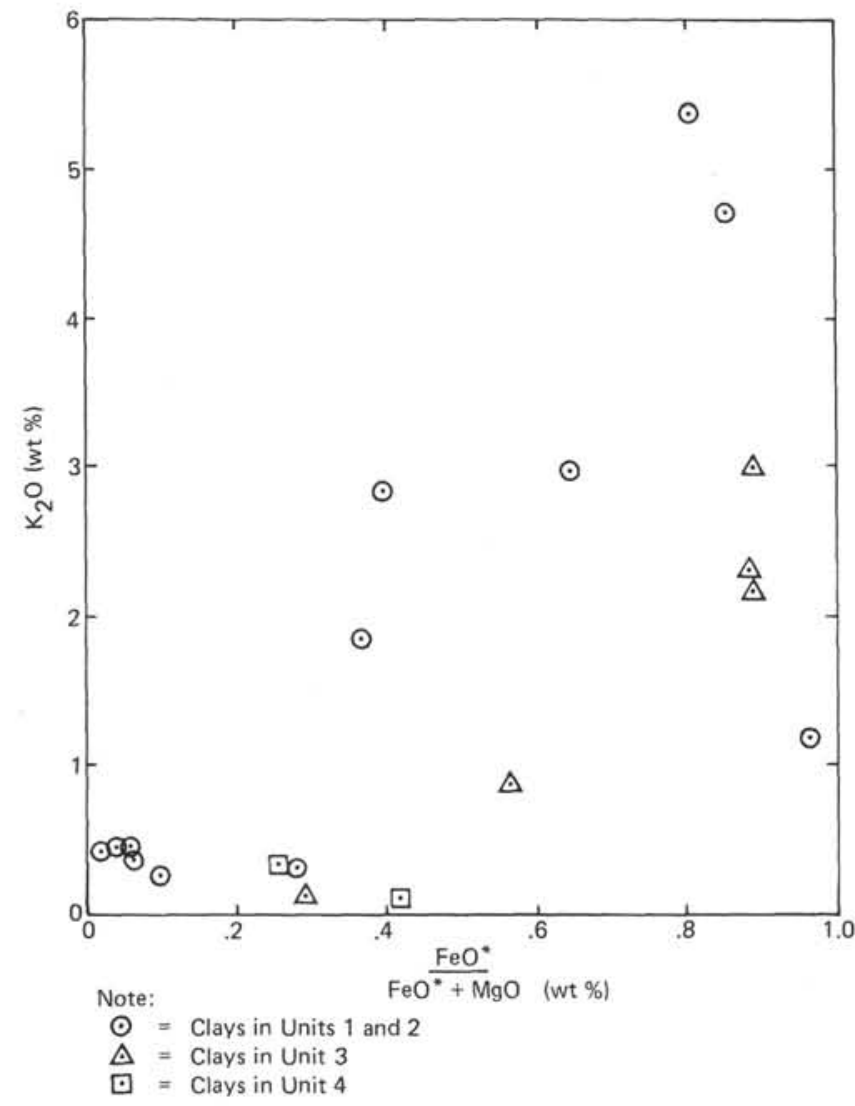

Figure 1. $\mathrm{K}_{2} \mathrm{O}$ versus $\mathrm{FeO}^{*} / \mathrm{FeO}^{*}+\mathrm{MgO}$ in some clays from Hole 396B. (See Table 2 for microprobe data.) it is buried deeper and deeper as it moves away from the spreading center. One can conceive that a continuous series of overlapping alteration processes affects the lava as soon as it is erupted. Deuteric alteration starts during the late magmatic stage, when residual magmatic fluids alter the early formed igneous minerals and the basaltic matrix as the lava body cools down. The posteruptive weathering progressively takes over the deuteric alteration, and seawater reacts, at bottom temperatures, with the almost cooled lava. This process continues as the lava body is progressively buried under sediments and moves along with the spreading sea floor. Reaction temperatures exponentially decrease from a few hundred to a few degrees centigrade, as the nature of the altering solutions gradually changes from that of residual magmatic fluids to seawater. At first, seawater can freely circulate above and through the lava body along the cooling surfaces and open fissures, but progressively its movements are restricted as the lava unit is buried under sediments and younger lavas, and the fissures are choked up ("healed") by secondary minerals. According to current ideas (Spooner and Fyfe, 1973; Chapman et al., 1975; Lister, 1975; Wolery and Sleep, 1975), the oceanic crust may be altered locally by seawater-derived solutions which are heated at the contact of the ridge intrusions and circulated along fault zones. The already deuterically altered and weathered lavas are then undergoing hydrothermal alteration, at increasingly higher temperatures and pressures. This last process has been called "ocean floor metamorphism"' by Miyashiro (1973). On the basis of the site survey data, the shipboard heatflow measurements and hole logging, we can safely assume that no hydrothermal activity is taking place now at the site of Hole 396B.

The two major characteristics of this alteration sequence are the progressiveness of the succession and the fact that the systems remain open for a long time. These various alteration processes not only affect the mineral and chemical composition of the oceanic crust as well as its physical properties, but they also affect the composition of the pelagic sediments, that of their pore waters, and eventually the chemistry of the bottom waters.

The study was designed to give the basis for interpreting the cumulative changes taking place with alteration in the physical and chemical properties of the upper layers of the oceanic crust. We have attempted to correlate the various modifications of the mineralogical and chemical composition of the submarine basalts during the alteration sequence by determining the mineralogical nature and the chemical composition of the authigenic minerals, the bulk 
chemical compositions of the rocks at various stages of alteration, and the various elemental exchanges between the crystalline rocks and the circulating fluids.

The present paper represents more a progress report of our work within one year after the end of the cruise, than a final and complete contribution. Our conclusions, therefore, have a preliminary value since the study is not completed yet, and one must expect further modifications when data such as oxygen isotopes measurements will be integrated with our own expanded data.

\section{PREVIOUS WORK ON THE LOW TEMPERATURE ALTERATIONS OF NON-GLASSY BASALTS}

Basaltic glasses forming submarine volcaniclastic rock (hyaloclastites, pillow rind breccias, etc.) are the most strongly and quickly weathered basaltic material because their finely divided structure exposes the largest glass surface to seawater. On the other hand, the glassy crusts of pillow lavas and lava flows of similar age and composition are not so strongly and rapidly altered as the glass of the volcaniclastic rocks. In their turn, the glassy rinds and the non-glassy inner parts of the pillow-lavas alter at different rates, and these rates vary in different ways through time. It is essential, therefore, to consider separately the submarine weathering of these various types of basaltic material. The effects of low temperature alteration on basaltic glasses from Hole 396B were not examined fully because of lack of time; only the non-glassy basalts were studied.

Submarine weathering of oceanic tholeiites is generally characterized by marked increases of the $\mathrm{K}_{2} \mathrm{O}, \mathrm{H}_{2} \mathrm{O}^{+}$, and $\mathrm{H}_{2} \mathrm{O}$ - contents, and the $\mathrm{Fe}_{2} \mathrm{O}_{3} / \mathrm{FeO}$ ratio while the $\mathrm{MgO}$, $\mathrm{CaO}$, and (to a lesser extent) the $\mathrm{SiO}_{2}$ contents decrease (S. Hart, 1969, 1971; Miyashiro et al., 1969; R. Hart, 1970, 1973a, b; Hekinian, 1971; Mathews, 1971; Shido et al., 1974). The changes with respect to $\mathrm{Al}_{2} \mathrm{O}_{3}, \mathrm{MnO}, \mathrm{Fe}$ total, $\mathrm{TiO}_{2}$, and $\mathrm{Na}_{2} \mathrm{O}$ are generally much smaller and quite variable; the various authors present contradictory data for these five oxides. According to S. Hart (1969), the seawater exchange during weathering results in an enrichment of $\mathrm{K}$ in the rock by a factor of 2 . The most extensive study of the halmyrolysis of non-glassy basaltic rocks, and one of the earliest which used DSDP samples, is the article by Thompson (1973). The data presented by Thompson (1973) confirm that $\mathrm{Si}, \mathrm{Mg}$, and $\mathrm{Ca}$ are the elements which are principally leached out of the tholeiites by weathering and that seawater $\mathrm{K}$ is accumulated in them; Thompson also states that $\mathrm{Al}, \mathrm{Fe}$ total, and $\mathrm{Mn}$ often are lost but to a lesser extent. The effects of weathering on $\mathrm{Na}$ and $\mathrm{Ti}$ are not clear according to Thompson, though the more altered rocks are markedly depleted in Na. Bass $(1974,1975,1976)$ fits the secondary mineralogy in several of the earlier DSDP cores into a hypothetical sequence of alteration stages. The secondary minerals he describes are very similar to those described here, but because we have concentrated so far on quantitative changes, we have been unable to confirm Bass' sequence.

\section{TRANSPARENT MINERAL PETROGRAPHY}

\section{Petrography and Alteration Features}

The petrography descriptions of the alteration features are summarized in Table 1 .

\section{Units 1 and 2 (150 to $235 \mathrm{~m}$, Cores 4 to 14)}

The aphyric basalts of the upper unit are aphanitic with a few scattered olivine and plagioclase phenocrysts. They are texturally zoned according to the typical pillow lava sequence from rim to core:

glassy $\rightarrow$ variolitic $\rightarrow$ subvariolitic (sheaf-like) $\rightarrow$ microcrystalline (intersertal, intergranular).

These gradational textures are illustrated in Plate 1, Figures 1 to 6 . The basalts range in color from dark gray to medium brown.

The most striking macroscopic feature of these rocks is the arrangement of brown bands which crisscross and surround rounded patches of gray basalt (Plate 2, Figure 1). The narrow (generally $<2 \mathrm{~cm}$ ) brown zones, or halos, run adjacent and concentric to veins, cracks, and exposed surfaces. At the contact between gray and brown is a narrow $(<2 \mathrm{~mm})$ " front" which appears from the geometry of the zones to have been advanced at the expense of the gray material. This front can take several forms, for example, the "black" and "light fronts" described below.

Zonation with a "black front" is exemplified in Sample $8-2,17-19 \mathrm{~cm}$ (2). The gray zone in this sample looks fresh, except for numerous calcite vug fills and possibly a very thin frosting of smectite coating some miarolitic voids. A sharp boundary separates the gray from a 2 to $3 \mathrm{~mm}$ dark band, i.e., the "black front," in which the primary minerals still appear relatively fresh, but where all vugs and vesicles are filled with olive-green to white translucent clay mineral \pm opaque oxides. The "black front" grades into the brown zone where olivine is completely replaced by brown cryptocrystalline material and where vugs and vesicles are only sparsely filled with orange isotropic clays, phillipsite, and/or opaque oxides.

Zonation with a "light front" is found in Sample 7-2, $96-98 \mathrm{~cm}(9)$. The gray zone in this sample has numerous vug linings and fillings of orange isotropic material and occasional opaque oxide and phillipsite fillings. The "front" in this sample is a 2 to $3 \mathrm{~mm}$ wide, light brown-gray band. Under the microscope, dense intersertal areas appear lighter in the front than in the gray zone, but the reason for this is not clear. The primary minerals appear fresh, and there are no particular vug fills. The brown zone behind the front has orange isotropic material as vug linings and fills, and also has abundant lighter-colored clays along with opaque oxides, phillipsite, and calcite. Sample 4-1, $103-105 \mathrm{~cm}$ (9) has a clay mineral-rich "black front" separating an inner gray zone (with calcite and a white clay mineral) from an outer, slightly discolored gray zone (with orange clay minerals and oxide vug linings). Complex interrelationships among the various zonation configurations are neatly shown in Sample 4-2, 10-13 cm (2) (Plate 2, Figure 1). A "fresh" gray core (with calcite and a little white translucent clay mineral) is surrounded by a green clay-rich "black front." Where this front is close to the exposure surface of the block, the zone behind it is brown. Where the "black front" protrudes farther into the block, the zone immediately behind it is discolored gray (with orange isotropic material in voids). This discolored gray zone passes into the brown zone near the block edge, across a "light front."

Olivine has undergone intense alteration in the brown zones. In some of the coarse-grained samples, replacement 
of granular olivine by brown, earthy, birefringent material is seen to be a major cause of the brown color of the rock. Comparisons of whole rock X-ray diffraction patterns of gray and brown samples show that olivine has practically disappeared in the brown zones, while plagioclase and pyroxene have remained in the same proportion. In the finer grained variolitic to subvariolitic rocks, olivine is not optically visible, but X-ray diffraction patterns indicate that submicroscopic olivine is present in the gray zones and again absent, except for a few large phenocrysts, in the brown zones.

Although often not optically visible, plagioclase and pyroxene appear fresh when observable. Whole rock X-rays show that they may occur in different proportions depending on rock texture but that the proportions do not vary with rock color. Opaque minerals are discussed in another section.

The secondary minerals found in veins and vugs in the aphyric pillow basalts include various smectites and poorly crystalline clay minerals, Fe-Mn oxides, $\mathrm{Na}>\mathrm{K}-$ phillipsite, and $\mathrm{Mg}_{4-8}$ calcite.

Glassy rims of the aphyric pillows seem to have been more resistant to alteration than the crystalline interiors, except for a narrow zone near the upper boundary of the variolitic zone, where there is often a row of intervariole orange patches of devitrified glass. No intersertal glass has been observed within the crystalline pillow interiors. Wholly or partly altered glass fragments in indurated ooze are common between pillows, but are not discussed here.

\section{Cooling Unit 3 (235 to $245 \mathrm{~m}$; Core 15)}

This core consists almost entirely of coarse intergranular to intersertal basalt (Plate 1, Figure 6). Color ranges from gray to brown-gray. In general, browner color occurs where veins and vugs are abundant, although there are exceptions, and the boundaries are diffuse in most instances. Nowhere in our samples is the rock as brown as in Units 1 and 2, but this may reflect only a textural difference. In Sample 15-3, 90-93 cm (3A), olivine is completely replaced by brown material, but the rock still looks grayish because the olivine granules are not finely dispersed. Smectites are abundant in all samples studied, both as vug fills and often as replacement of olivine granules.

There is a concentration in Section 15-3 of very large $(>1$ $\mathrm{cm}$ across) vugs that have complex fills of fibrous and botryoidal poorly to well crystallized clay minerals, botryoidal and nodular Mn-oxides, bulbous calcite, and acicular aragonite (Plate 2, Figure 2).

\section{Unit 4 (245 to $315 \mathrm{~m}$, Cores 16 to 22 )}

The porphyritic pillow basalts of this unit have textures similar to those of Units 1 and 2 (glassy $\rightarrow$ variolitic $\rightarrow$ subvariolitic $\rightarrow$ microcrystalline), with the difference being the abundance of plagioclase and lesser olivine phenocrysts (on the order of $5 \mathrm{~mm}$ in size). The rock is broadly zoned brown and gray with colors and patterns similar to those of Units 1 and 2 (Plate 2, Figure 3), except that transitional alteration zones are more common, and sharp alteration "fronts"' for the most part are absent. Whole rock X-rays of brown and gray samples show that here, too, olivine is absent in the brown zones. Plagioclase is often partly replaced by calcite very close to veins, and one instance has been found of phillipsite replacing plagioclase (Sample 20-2, 130-135 cm (9F).

Cracks and vugs are filled, as in Units 1 and 2, with clay minerals, Fe-Mn oxides, phillipsite, and calcite. Rock fragments are also common in veins in Unit 4, perhaps because the heterogeneity of the porphyritic basalt caused it to crumble when it broke.

\section{Unit 5 (315 to $216.5 \mathrm{~m}$, Core 23 )}

This unit was not well-sampled, but a suite of interesting rocks was recovered near the top of Core 23. These have a greenish gray color, sugary texture, and what appears to be flow banding. Under the microscope, these rocks are seen to be fine granular intergrowths of plagioclase, clinopyroxene, and frequent relicts of olivine, with abundant opaque oxides.

Dull pinkish brown zones (about $1 \mathrm{~cm}$ wide) occur next to some veins in these rocks much the same as in the other units. $\mathrm{X}$-ray diffraction patterns show that in Core 23, olivine is absent from both the brownish and the green-gray zones having been altered to smectites, Fe-oxides, and/or calcite.

\section{Veins}

Brown zones (oxidation zones) in the pillow basalts are often centered on veins (Plate 3, Figures 1 to 5). Parallel walls and the fact that they split some phenocrysts, indicate that the veins are filled cracks. Vein fills in Units 1,2 , and 4 are generally one of two types - zoned or mixed.

Zoned vein fills are concentrically zoned as follows, from rim to core: (1) light orange to greenish yellow or grayish clay mineral (smectite); (2) discontinuous botryoidal opaque material ( $\mathrm{Fe}+\mathrm{Mn}$ oxides); (3) phillipsite clusters terminating inward in euhedral prisms; and (4) clear bulbous calcite masses, or granular calcite with suspended phillipsite needles.

The mineral habits suggest that this sequence is a sequence of mineral deposition from solution onto the walls of the cracks. Thinner veins have only the first part of the sequence, having been completely filled by the first few layers.

An exceptional vein in Sample 7-2, 96-98 cm (9) has an additional thin fibrous calcite layer along one side of the normal sequence (Plate 3, Figure 3). Apparently, the crack was filled by the normal series of deposits, then reopened and filled again with the last-precipitating phase (calcite).

Several vertically oriented cracks are filled below a certain level with a mixture of anhedral phillipsite with dispersed Fe-Mn oxides and clay material. Above that level, the concentrically zoned normal sequence of vein deposits is present (see Plate 3, Figures 4 and 5). The cracks open upward, so that the lower parts are the narrowest. The "mixed"'vein fill may be cemented and altered clastic material that fell to the bottoms of the cracks, or it may represent rapid simultaneous precipitation of the vein phases in the innermost restricted parts of the cracks. The upper fill represents later, orderly precipitation. If the contacts are geopetal surfaces, then they might conceivably be useful as tilt indicators. In one sample $(12-1,27-29 \mathrm{~cm}$ [3]) where the contact could be traced, it is very straight and trends about $15^{\circ}$ from horizontal (as determined from the magnetic orientation arrows). A few veins from Core 15 (Unit 3) are zoned in the sequence described above, but without 
TABLE 1

Petrographic Summary of Hole 396B

\begin{tabular}{|c|c|c|c|c|c|c|c|c|c|c|c|c|c|c|c|}
\hline \multirow[b]{2}{*}{$\begin{array}{l}\text { Sample No. } \\
\text { (Interval in cm) }\end{array}$} & \multicolumn{4}{|c|}{ Texture ${ }^{a}$} & \multicolumn{3}{|c|}{ Oxidation of Olivine } & \multicolumn{8}{|c|}{ Clay Patches and Vug Fills ${ }^{\mathrm{b}}$} \\
\hline & Varis & olitic & $\begin{array}{c}\text { Sub- } \\
\text { variolitic }\end{array}$ & Intersertal & $\begin{array}{l}\text { Gray } \\
\text { Rock }\end{array}$ & Mixed & $\begin{array}{l}\text { Brown } \\
\text { Rock }\end{array}$ & $\begin{array}{c}\begin{array}{c}\text { Orange } \\
\text { (Not }\end{array} \\
\text { Birefringent) }\end{array}$ & $\begin{array}{l}\text { Olive } \\
\text { to } \\
\text { Muddy } \\
\text { Green }\end{array}$ & $\begin{array}{l}\text { Dark } \\
\text { Brown }\end{array}$ & $\begin{array}{c}\text { Deep } \\
\text { Red } \\
\text { Brown }\end{array}$ & $\begin{array}{l}\text { Light } \\
\text { Orange } \\
\text { Brown }\end{array}$ & $\begin{array}{l}\text { Yellow } \\
\text { Green }\end{array}$ & $\begin{array}{l}\text { Buff- } \\
\text { White }\end{array}$ & Other \\
\hline & 1 & 2 & 34 & 56 & & & & & & & & & & & \\
\hline $4-1-1,14-17$ & $\mathrm{x}$ & & & & & & $\mathrm{x}$ & $\mathrm{x}$ & & & & & & & \\
\hline $4-1-2,22-24$ & & & & $\mathrm{x}$ & & & $\mathrm{x}$ & $\mathrm{x}$ & & & & & & & \\
\hline $4-1-9,103-105$ & & & 0 & & 0 & & & 00 & & & & & & & \\
\hline $4-1-9$, near vein & & & 0 & & 0 & & & & & $0^{\mathrm{r}}$ & & & & $0^{c}$ & \\
\hline $4-2-9,57-59$ & & $\mathrm{x}$ & $\mathrm{x}$ & & & & $\mathrm{x}$ & $\mathrm{x}$ & & & & & & & \\
\hline $5-1-9,86-88$ & & & 0 & & 0 & & & (0) & & & & & & & \\
\hline $5-2-2,9-11$ & 0 & & & & 0 ? & & & & & & & & & & \\
\hline $5-2-2,9-11$ & $\mathrm{x}$ & & & & & & $\mathrm{x}$ & $\mathrm{x}$ & $(\mathrm{X})$ ? & & & & & & \\
\hline $5-2-2,12-14$ & & & $\mathrm{x}$ & & & & $\mathrm{x}$ & & & & & & & & \\
\hline $5-2-4,28-31$ & & 0 & & & 0 & & & 0 & & & & & & & \\
\hline $5 \cdot 2-4,28-31$ & & $\mathrm{x}$ & & & & & $\mathrm{x}$ & $\mathrm{x}$ & & & & & & & \\
\hline $5-2-5,32-34$ & & & 0 & & 0 & & & & & $0^{\mathrm{r}}$ & & & & $0^{\mathrm{c}}$ & \\
\hline $6-1-5,36-38$ & & & $\mathrm{x}$ & $\mathrm{x}$ & & $\mathrm{x}$ & & $\mathrm{x}$ & & & & & & & \\
\hline $6-1-7,55-57$ & & & 0 & & 0 & & & & & & & & & 0 & \\
\hline $6-1-7$, near vein & & & Q & & & $\otimes ?$ & & & (இ) & & $\otimes^{r}$ & $\otimes \otimes$ & & & \\
\hline $6-1-14,109-111$ & & $\mathrm{x}$ & $\mathrm{x}$ & & & & $\mathrm{x}$ & & & & & & & & \\
\hline $7-1-12,145-147$ & & & & 0 & 0 & & & & 0 & & & & & 00 & \\
\hline $7-1-12,142-144$ & & & & $\mathrm{x}$ & & & $\mathrm{x}$ & & & & & & & & \\
\hline $7-2-4,34-36$ & & & $\mathrm{x}$ & & & & $\mathrm{X}$ & (X) & & & & & & & \\
\hline $7-2-5,47-49$ & & & 0 & & 0 & & & (0) & & & & & & & \\
\hline $7-2-5,47-49$ & & & $\mathrm{x}$ & & & & $\mathrm{x}$ & $\mathrm{x}$ & & & & & & & \\
\hline $7-2-9,96-98$ & & 0 & & & 0 & & & 0 & & & & & & & \\
\hline $7-2-9,96-98$ & & $\mathrm{x}$ & & & & & $\mathrm{x}$ & $\mathrm{x}$ & & & & & $\mathrm{X}^{\mathrm{r}}$ & $x^{c}$ & \\
\hline $8-1-3,21-23$ & & (Q) & Q & & & $\otimes$ & & (இ) & & & & & $(\otimes)^{r}$ & $(x)^{\circ}$ & \\
\hline $8-1-8 \mathrm{~A}, 62-64$ & & & 0 & & 0 & & & & & & $0^{x}$ & $00^{\mathrm{c}}$ & & & \\
\hline $8-1-13,118-120$ & 0 & & & & & 0 ? & & & & & & & & & \\
\hline $8-1-13,118-120$ & $\mathrm{x}$ & & & & & $\mathrm{X}$ ? & & & & & & & & & \\
\hline $8-1-13,114-116$ & & $\mathrm{x}$ & & & & & $\mathrm{x}$ & $\mathrm{x}$ & & & & & & & \\
\hline $8-1-16,145-149$ & & & & $\mathrm{x}$ & & $\mathrm{x}$ & $\mathrm{x}$ & $\mathrm{x}$ & & & & & & & \\
\hline $8-2-2,17-19$ & & & & 0 & 0 & & & & & & & & & (0) & \\
\hline $8-2-2,17-19$ & & & & $\otimes$ & Q? & & & & $(x x)$ & & & & & Q & \\
\hline $8-2-2,17-19$ & & & & $\mathrm{x}$ & & & $\mathrm{x}$ & $\mathrm{x}$ & & & & & & & \\
\hline $12-1-1,9-11$ & & & 0 & & 0 & & & & & & $0^{\mathrm{r}}$ & $0^{\mathrm{c}}$ & & 0 & \\
\hline $12-1-3,27-29$ & & & $\mathrm{x}$ & & & & $\mathrm{x}$ & (X) & & & & & & & \\
\hline $12-1-(8 \mathrm{~A}), 127-129$ & & & & 0 & 0 & & & & & & $0^{r}$ & $00^{\mathrm{c}}$ & & & \\
\hline $15-2-2 \mathrm{C}, 126-128$ & & & & $\rightarrow$ & 0 & & & & 00 & & & & & & \\
\hline $15-3-3 \mathrm{~A}, 90-93$ & & & & $\mathrm{x}$ & & & $\mathrm{x}$ & & $\mathrm{x}$ & & $\mathrm{x}$ & & & $\mathrm{x}$ & $1,2,3,4$ \\
\hline 15-3-3D, 105-109 & & & & $\mathrm{x}$ & & $\mathrm{x}$ & & & $\mathrm{x}$ & & $\mathrm{x}$ & & & & 2,3 \\
\hline $16-4-1,11,92-96$ & & & & 0 & 0 & & & & 0 & & & & & & \\
\hline $20-2-(5 A), 51-53$ & & & 0 & & 0 & & & & & & $0^{\mathrm{r}}$ & $00^{\mathrm{c}}$ & & & \\
\hline $20-2-(9 A), 94-96$ & & & $\mathrm{x}$ & & & & $\mathrm{x}$ & (X) & & & & & & $(\mathrm{X})$ & \\
\hline 20-2-(9F), 130-135 & & & $\mathrm{x}$ & & & & $\mathrm{x}$ & & & & & & & (X) & \\
\hline 20-5-9B, $75-79$ & & $\mathrm{x}$ & & & & & $x$ & & & & & & & $x$ & $\begin{array}{l}\text { black- } \\
\text { green }\end{array}$ \\
\hline $23-1-2,8-11$ & & & & & & & & $\mathrm{X}$ ? & $\mathrm{X}$ ? & & & & & & \\
\hline $23-1-4,18-24$ & & & & & & & & $\mathrm{X}$ ? & $\mathrm{X}$ ? & & & & & & \\
\hline
\end{tabular}

Note: $0=$ gray zone, $(0)=$ very minor, $0=$ common, $00=$ abundant, $Q$ ) $=$ transitional (frontal) zone, $X=$ brown zone.

a Textures correspond roughly with the sequence illustrated in Plate 1, Figures 1-6.

${ }^{\mathrm{b}}$ Clay colors are as seen in hand specimen, $\mathrm{r}=\mathrm{rim}, \mathrm{c}=$ core. 
TABLE 1 - Continued

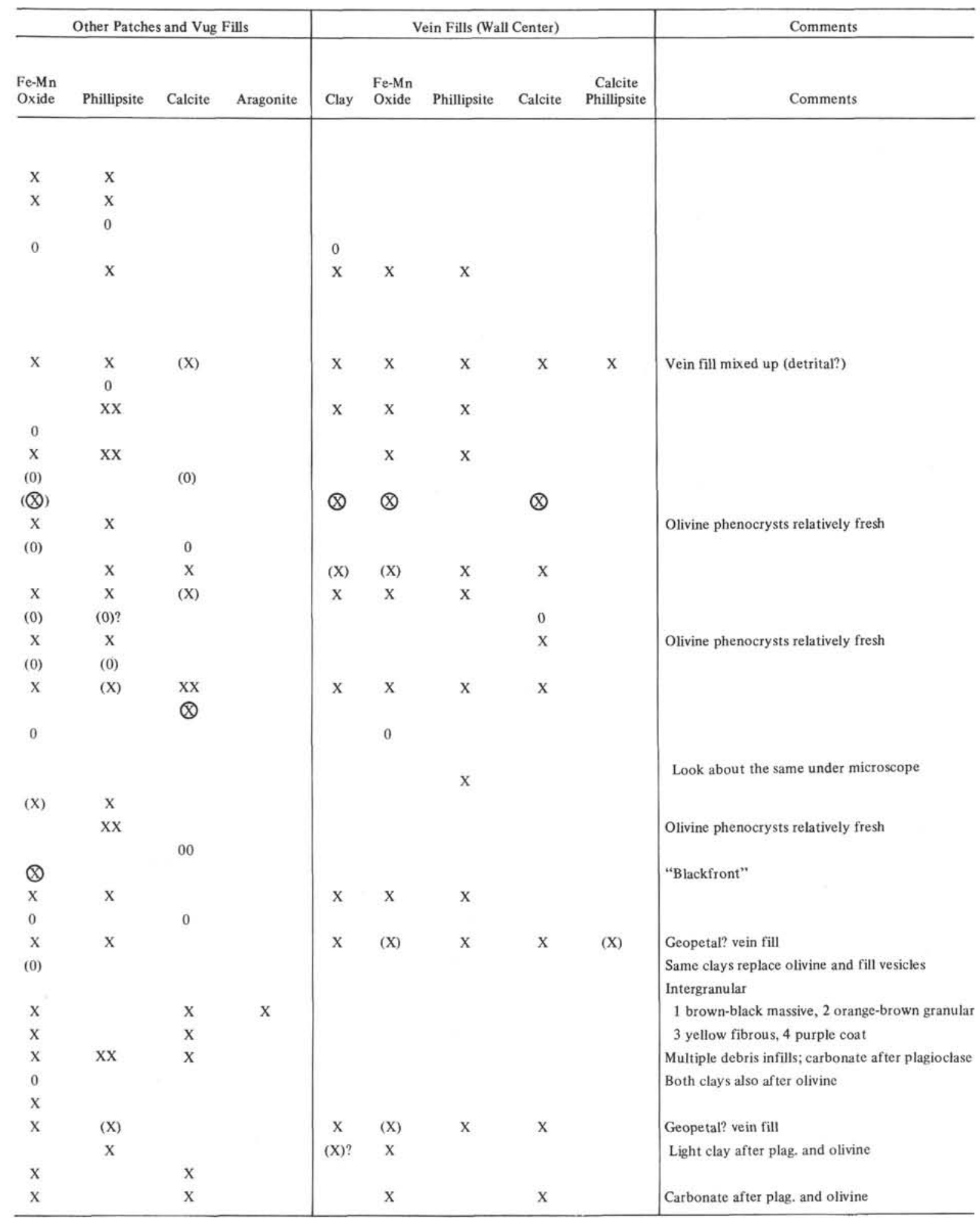

Note: $0=$ gray zone, $(0)=$ very minor, $0=$ common, $00=$ abundant, $X)=$ transitional (frontal) zone, $X=$ brown zone.

a Textures correspond roughly with the sequence illustrated in Plate 1, Figures 1-6.

${ }^{b}$ Clay colors are as seen in hand specimen, $\mathrm{r}=\operatorname{rim}, \mathrm{c}=$ core. 
phillipsite. One such vein (in Sample 15-1, 133-139 cm [12]) has distinctly non-parallel walls, and a core of large curved flakes of a transparent phyllosilicate.

\section{Vugs}

Vesicles (mostly 0.1 to $0.2 \mathrm{~mm}$ across) and miarolitic voids (to $>1 \mathrm{~cm}$ ) are common to abundant throughout the hole. Miarolitic voids often appear to grade into vesicles, suggesting that both types of voids are related. They both are filled in the same way by secondary minerals. The fills are partial or complete, and commonly consist of several layers. The sequences of fills in vugs are less consistent than in the veins, and often complex because of the variety of clays that are found in them. The fact that most vugs are empty now, and that zoned botryoidal (clays, opaques) and euhedral (phillipsite) linings and partial fills coat the walls in much the same way as they do in veins, suggests that the secondary mineral fills are not replacements, but that they grew into pre-existing voids.

One of the peculiarities of miarolitic voids is that unusually large pyroxene and titanomagnetite grains are found protruding into them (Plate 4, Figure 1). The large crystal growth may be related to concentrations of volatiles in certain areas, which were evacuated later, leaving voids. In several large (cm size) vugs in Cores 14-16, a fibrous, pleochroic phase occurs as oriented overgrowths on pyroxene crystals protruding from the walls.

\section{SECONDARY MINERALS}

X-ray diffraction patterns of whole-rock powders were obtained from a Phillips-Norelco diffractometer. Individual minerals from veins and vugs were scratched into powder, mounted on glass fibers, and run in Debye-Scherrer cameras using $\mathrm{Fe}$ radiation and $\mathrm{Mn}$ filter. A 57.3- $\mathrm{mm}$ camera was used for rapid identification by comparison with standard patterns. Mg-calcites were run in a $114.6-\mathrm{mm}$ camera with $\mathrm{KCl}$ as internal standard. Clay minerals, mounted first with vaseline and then with a drop of ethylene glycol, were also run in the $114.6-\mathrm{mm}$ camera. The clay minerals required exposure time (in $\mathrm{Fe}$ radiation) of up to 20 hours.
Microprobe analyses of secondary minerals were done on a Cambridge Microscan 5 probe at the University of Maryland with the help of Dr. Sheldon Sommer, Department of Chemistry. The correction program used is MAGIC IV by J.W. Colby, adapted for minicomputer by L.W. Finger. Standards used were the Kakanui hornblende (major elements) and Ilmenite NMNH 96189 (Fe-Mn-Ti ratios) supplied by E. Jarosewich, Smithsonian Institution. Specimen current was $0.04 \mu \mathrm{A}$; voltage $+20 \mathrm{kV}$; spot size $\sim 20 \mu \mathrm{m}$.

The oxide totals for clay mineral analyses were rather low $(50-80 \%)$. Much of the deficiency is due to the high water content of smectites. Other contributors might be poor surface conditions (resulting from undercutting of the soft materials in polishing) or contamination by epoxy in or under the specimen surface. SEM work has shown that many of the clay mineral fills are extremely porous.

\section{Clay Minerals}

Clay minerals here comprise a group of soft, often colored phases that occur as fillings and linings of veins, vugs, and other intersertal areas (Plates 3 and 4). In at least two samples - $(20-2,51-53 \mathrm{~cm}[5 \mathrm{~A}]$ and $12-1,127-129 \mathrm{~cm}$ [8]) - olivine is partly replaced by clay minerals that are optically identical to vug fillings in the same samples; the same is true for plagioclase phenocrysts in one instance $(20-5,75-79 \mathrm{~cm}[9 \mathrm{~B}])$. Most of the phases described here are birefringent and display extinction patterns suggestive of fibrous habit, but some are nearly isotropic, have low $\mathrm{Si}+$ Al contents, give very poor X-ray patterns, and are obviously not pure clay minerals.

\section{Units 1 and 2}

The general distribution of clay minerals is shown in Table 1. The colors (as seen in hand specimen) range from white-translucent to red-orange and deep olive-green.

The most ubiquitous material (although usually in small amounts), is isotropic and displays a bright orange color. It occurs as small intersertal patches and as vesicle and vug linings, where it may be succeeded inward by Fe-Mn oxides and/or phillipsite. This material is Fe rich (see Table 2,

TABLE 2

Selected Microprobe Analyses of Clay-Like Patches ${ }^{\mathrm{a}}$

\begin{tabular}{|c|c|c|c|c|c|c|c|c|c|c|c|c|c|c|c|c|c|c|c|}
\hline & 1 & 2 & 3 & 4 & 5 & 6 & 7 & 8 & 9 & 10 & 11 & 12 & 13 & 14 & 15 & 16 & 17 & 18 & 19 \\
\hline $\mathrm{SiO}_{2}$ & 39.88 & 59.83 & 47.78 & 53.70 & 59.85 & 65.04 & 59.37 & 63.18 & 50.68 & 55.50 & 57.53 & 55.03 & 43.13 & 37.33 & 42.21 & 45.45 & 50.75 & 42.17 & 53.19 \\
\hline $\mathrm{TiO}_{2}^{\mathrm{b}}$ & 1.15 & 0.02 & 0.03 & 0.00 & 0.04 & 0.02 & 0.03 & 0.01 & 0.01 & 0.01 & 0.07 & 0.00 & 0.01 & 0.00 & 0.08 & 0.01 & 0.02 & 0.01 & 0.02 \\
\hline $\mathrm{Al}_{2} \mathrm{O}_{3}$ & 7,45 & 3.44 & 3.94 & 0.97 & 3.91 & 2.05 & 2.50 & 2.08 & 3.13 & 3.22 & 7.57 & 5.66 & 0.22 & 0.12 & 9.22 & 2.44 & 2.41 & 8.89 & 9.07 \\
\hline $\mathrm{FeO}^{*}$ & 46.53 & 2.15 & 28.30 & 34.22 & 12.09 & 1.86 & 13.73 & 1.24 & 12.26 & 3.87 & 22.98 & 0.87 & 47.66 & 42.09 & 13.93 & 42.66 & 24.64 & 19.52 & 9.09 \\
\hline $\mathrm{MnO}^{\mathrm{b}, \mathrm{c}}$ & 0.07 & n.a. & n.a. & n.a. & n.a. & n.a. & n.a. & n.a. & 0.06 & n.a. & 0.03 & n.a. & 0.23 & 11.58 & n.a. & n.a. & 0.06 & 1.09 & 0.66 \\
\hline $\mathrm{MgO}$ & 1.47 & 33.18 & 15.10 & 5.41 & 20.85 & 30.11 & 20.84 & 32.75 & 31.75 & 36.12 & 5.30 & 37.27 & 5.53 & 5.09 & 33.58 & 5.14 & 19.68 & 27.92 & 26.68 \\
\hline $\mathrm{CaO}$ & 1.56 & 0.81 & 0.60 & 0.51 & 0.96 & 0.32 & 0.53 & 0.18 & 0.35 & 0.29 & 0.64 & 0.40 & 0.98 & 1.33 & 0.68 & 1.18 & 1.32 & 0.15 & 0.72 \\
\hline $\mathrm{Na}_{2} \mathrm{O}^{\mathrm{b}}$ & 0.71 & 0.19 & 1.28 & 0.50 & 0.45 & 0.17 & 0.18 & 0.12 & 1.47 & 0.71 & 0.52 & 0.35 & 0.03 & 0.15 & 0.17 & 0.12 & 0.24 & 0.19 & 0.22 \\
\hline $\mathrm{K}_{2} \mathrm{O}$ & 1.18 & 0.37 & 2.97 & 4.70 & 1.85 & 0.42 & 2.82 & 0.44 & 0.30 & 0.27 & 5.37 & 0.42 & 2.21 & 2.32 & 0.13 & 3.00 & 0.88 & 0.06 & 0.35 \\
\hline $\mathrm{FeO} * / \mathrm{FeO}^{*}+\mathrm{MgO}$ & 0.97 & 0.06 & 0.65 & 0.86 & 0.37 & 0.06 & 0.40 & 0.04 & 0.28 & 0.10 & 0.81 & 0.02 & 0.90 & 0.89 & 0.29 & 0.89 & 0.56 & 0.41 & 0.25 \\
\hline
\end{tabular}

Note: $1=4-1-2,22-24 \mathrm{~cm}$, brown block, orange isotropic interstitial patch: $2=6-1-7,55-57 \mathrm{~cm}$, gray zone, white translucent vug lining: $3=6-1-7,55-57 \mathrm{~cm}, 2-\mathrm{mm}-$ wide transitional zone next to vein, dark red-brown vug lining; $4=6-1-7,55-57 \mathrm{~cm}, 2 \mathrm{~mm}-\mathrm{wide}$ transitional zone next to vein, light orange-brown vug center; $5=7-2-9,96-98 \mathrm{~cm}$, brown zone, light yellow-green vug lining; $6=7-2 \cdot 9,96-98 \mathrm{~cm}$, brown zone, white translucent vug center, smectite good basal peak; $7=8-1-3,21-23 \mathrm{~cm}$, mixed, light yellow-green vug lining; $8=8-1-3,21-23 \mathrm{~cm}$, mixed, white translucent vug center; $9=8-1-8 \mathrm{~A}, 62-64 \mathrm{~cm}$, gray zone, bright red-orange vesicle lining; $10=8-1-8 \mathrm{~A}, 62-64 \mathrm{~cm}$, gray zone, light orange-brown vesicle center, smectite-broad basal peak; $11=$ $8-2-2,17-19 \mathrm{~cm}$, in the "black front," olive-green vug lining, "glauconite-like," very diffuse basal peak; $12=8-2-2,17-19 \mathrm{~cm}$, in the "black front," white translucent vug center, smectite-good basal peak: $13=15-3-3 \mathrm{~A}, 90-93 \mathrm{~cm}$, brownish rock, muddy-green vug lining, "glauconite-like," very diffuse basal peak; $14=15-3-3 \mathrm{~A}, 90-93 \mathrm{~cm}$, brownish rock, brown-black streaks an patches in vug lining, "glauconite-like," very diffuse basal peak $+7 \AA$ Mn-oxide phase; $15=15-3-3 \mathrm{D}, 105-109 \mathrm{~cm}$, brownish rock, yellow fibrous growth on pyroxene protruding into vug, smectite-good basal peak; $16=15-3-3 \mathrm{D}, 105-109 \mathrm{~cm}$, brownish rock, green-orange bulbous growth on wall of vug; $17=15 \cdot 3 \cdot 3 \mathrm{D}, 105-109 \mathrm{~cm}$, brownish rock, orange-brown granules an patches in mass; $18=20-5-9 \mathrm{~B}, 75-79 \mathrm{~cm}$, brown tock, dark green vesicle fill giving chlorite $\mathrm{x}$-ray diffraction pattern; $19=20-5-9 \mathrm{~B}, 75-79 \mathrm{~cm}$, brown rock, white translucent vug lining.

a wh. F oxides recalculated to $\Sigma$ major oxides $=100 \%$, most are representative of several analyses of optically similar material that gave practically identical results.

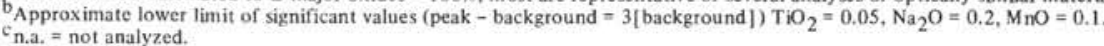


column 1) and also contains far more $\mathrm{Ti}$ than any of the other clays.

A very thin lining of birefringent material which can be yellow, greenish, orange, or gray within one sample, coats the walls of nearly all veins. X-ray diffraction patterns of several of these coatings with different colors show that they are all smectites. Partial microprobe analyses in Samples $7-2,34-36 \mathrm{~cm} \mathrm{(4)} \mathrm{and} \mathrm{7-2,} \mathrm{96-98} \mathrm{cm}$ (9) suggest that the vein lining smectites have $\mathrm{Mg}>\mathrm{Fe}$.

The rest of the clay minerals in Units 1 and 2 seem to be confined to the gray or transitional (frontal) zones; only one brown zone, in Sample 7-2, 96-98 cm (9), is included in this group. These phases range in composition from $\mathrm{Fe}>\mathrm{Mg}$ to $\mathrm{Mg}>>\mathrm{Fe}$. Typically, they occur as pairs, a darker one as an outer lining on the walls of vugs and vesicles, and a lighter colored one in the center. With one exception (Sample 6-1, 55-57 cm [7]), the darker rims have higher iron content than the lighter centers (Table 2, columns 3 to 12). The difference can be relatively small (columns 5 to 10) or rather large (columns 11 and 12).

In general, the light colored materials are Mg-rich and give good trioctahedral smectite X-ray patterns. Dark clays, both orange and green, may be Fe-rich. Repeated X-rays of the olive-green clays from the "black front" of Sample 8-2, $17-19 \mathrm{~cm}(2)(\mathrm{Fe}>\mathrm{Mg})$ give a good series of hk reflections but only a very diffuse halo near $10-11 \AA$.

Sample 8-2, 17-19 cm (2) illustrates the complexity and mobility of the clay minerals as vug fills. All the voids within the "black front" are filled with clay mineral, whereas most of the vugs in the brown and gray zones on either side of the front are empty or only thinly coated with different clay minerals. If one assumes that the front has advanced through the rock, then certain individual vugs must have gone through stages of being filled, emptied, and relined with different clay minerals as they became part of the black front and brown zone, respectively.

Clay minerals from other units have not yet been studied fully, but some noteworthy features will be mentioned.

\section{Cooling Unit 3}

A couple of samples from the vuggy part of Section 15-3 have rather complex assemblages of clay minerals and mixed oxides. For example, a vug in Sample 15-3, 90-93 $\mathrm{cm}(3 \mathrm{~A})$ has a thick bulbous lining of muddy green clay (diffuse basal reflection, $\mathrm{Fe}>\mathrm{Mg}$ ) with inclusions of brown to black material that apparently is the same clay with dispersed Mn oxide (see Table 2, columns 13 and 14; Plate 4, Figure 5). This thick lining has a very thin purple birefringent coat (very high $\mathrm{Fe}$ ) which is overlain by nodular Mn oxide. A very well crystallized (fibrous, yellow, pleochroic) $\mathrm{Mg}>\mathrm{Fe}$ smectite occurs as overgrowths on pyroxenes projecting into calcite-filled vugs in Sample 15-3, 105-109 cm (3D) (see Table 2, column 15; Plate 4, Figure 6).

In the groundmass, there are abundant granules and patches of orange-brown material that seems to have taken the place of much of the olivine (see Table 2, column 17) and also small vug linings and fills of light colored material very similar to the light $\mathrm{Mg}$-rich smectites of Units 1 and 2.

Sample $15-2,126-128 \mathrm{~cm}(2 \mathrm{C})$ is quite fresh in terms of primary minerals, but has a green-black smectite filling all of its voids.

\section{Lower Units}

The only unusual clay minerals discovered so far in the lower units are (1) a whitish vein lining in Sample 16-2, $117-124 \mathrm{~cm}(10)$, that has an X-ray diffraction pattern that resembles talc, and (2) a greenish greasy-looking vein lining in Sample 23-1, 8-11 cm (2) with an X-ray pattern similar to chlorite. Probe analyses of a couple of vug fills from Sample 20-5, 75-79 cm, (9B) are given in Table 2 (Columns $18,19)$. The dark green vesicle fills, represented by analysis 18 give chlorite $\mathrm{X}$-ray patterns. Further X-ray diffraction camera work is in progress to better characterize the smectites in Units 1 and 2, and to confirm and search for the existence of other layer silicates in the lower units.

\section{Summary}

The major features of clay mineral chemistry have been discussed briefly in the foregoing description. Of particular importance to alteration studies are the $\mathrm{Fe} / \mathrm{Mg}$ ratio and the $\mathrm{K}$ content. Figure 1 shows that these two parameters may be systematically related. In general, the distribution of $\mathrm{K}_{2} \mathrm{O}$ vs. $\mathrm{FeO} * / \mathrm{FeO}^{*}+\mathrm{MgO}$ of all analyzed clay minerals is such that $\mathrm{K}_{2} \mathrm{O}<6.5 \times\left(\mathrm{FeO}^{*} / \mathrm{FeO}^{*}+\mathrm{MgO}\right)$. In other words, Fe-rich clay minerals have more $\mathrm{K}$ than $\mathrm{Mg}$-rich clay minerals. Furthermore, clay minerals in the massive Unit 3 (Core 15) have lower $\mathrm{K}$ contents than clay minerals in Units 1 and 2 , for the same $\mathrm{FeO}^{*} / \mathrm{FeO}^{*}+\mathrm{MgO}$. The only exception to both rules is the orange isotropic material that is nearly ubiquitous in Units 1 and 2 , and which probably does not represent a single crystalline phase. The significance of these relations is not clear, but is important to note that the most $\mathrm{K}$ contained in clay minerals is found in the narrow "'black fronts," not in the most altered parts of the basalt (i.e., brown zones). In the "black front" of Sample 8-2, 17-19 cm (2), a dark green vug lining (represented by analysis 11) gave a glauconite-like X-ray pattern, suggesting that the systematic variation in clay mineral chemistry may reflect varying proportions of saponite $(\mathrm{Mg})$ with a mica $(\mathrm{Fe}, \mathrm{K})$ as submicroscopic mixtures or mixed-layer phases.

\section{Fe-Mn Oxides}

Opaque bulbous and nodular vein and vug linings ana fills are common throughout the hole. A survey of Fe-Mn ratios calculated from partial microprobe analyses is given in Table 3. It is obvious that the ratio is highly variable between the two almost pure end members.

A few X-rays have shown that both $10 \AA$ and $7 \AA$ manganese oxides are present in veins and in vugs, but more work is needed to see if there are any distributional patterns.

\section{Phillipsite}

Phillipsite has been identified in X-ray diffraction camera patterns of vein and vug fills from all units except the massive Unit 3. Phillipsite occurs as radial euhedral prismatic crystal clusters or massive fills in veins and vugs. Several fills have textures suggesting that detritus (perhaps glass fragments) was sedimented in and later replaced by anhedral phillipsite with dispersed $\mathrm{Fe}-\mathrm{Mn}$ oxide and/or smectites. In one instance (Sample 20-2, 130-135 cm, [9F]) phillipsite apparently replaces plagioclase near a vein.

Microprobe analyses of several phillipsites from vug and vein fills in Samples 4-1, 22-24 cm (2) and 8-2, 17-19 cm 
TABLE 3

Compositions of Some Secondary Brown to Black (opaque) Fills ${ }^{\mathrm{a}}$

\begin{tabular}{|c|c|c|c|}
\hline $\begin{array}{c}\text { Sample } \\
\text { (Interval in cm) }\end{array}$ & Description & $\begin{array}{l}\mathrm{Fe}+\mathrm{Mn} \text { Color } \\
\text { (molar) }\end{array}$ & \\
\hline $4-1-2,22-24$ & Bulbous mass in vesicle & 0.04 & Black \\
\hline $7-2-4,34-36$ & Vug fill and vesicle outer-lining & 0.13 & Black \\
\hline $7-2-4,34-36$ & Bulbous vesicle inner-lining & 0.05 & Black \\
\hline $7-2-4,34-36$ & Bulbous vein lining (over clay) & 0.26 & $\begin{array}{l}\text { Dark brown } \\
\text { to black }\end{array}$ \\
\hline $7-2-4,34-36$ & Patch suspended in phillipsite vein & 0.16 & $\begin{array}{l}\text { Datk brown } \\
\text { to black }\end{array}$ \\
\hline $7-2-9,96-98$ & Vesicle center (rimmed by clays) & 0.01 & Black \\
\hline $7-2-9,96-98$ & Vug fill & 0.05 & Black \\
\hline $7-2-9,96-98$ & Bulbous vein lining (over clay) & 0.36 & $\begin{array}{l}\text { Dark brown } \\
\text { to black }\end{array}$ \\
\hline $7-2-9,96-98$ & Patch suspended in phillipsite vein & 0.12 & Black \\
\hline $8-2-2,17-19$ & Vug center (timmed by clay) & 0.96 & Brown to black \\
\hline $8-2-2,17-19$ & Vug center (rimmed by clay) & 0.29 & Brown to black \\
\hline $8 \cdot 2 \cdot 2,17 \cdot 19$ & Vesicle center (rimmed by clay) & 0.98 & Brown to black \\
\hline $8 \cdot 2 \cdot 2,17-19$ & Bulbous vein lining (over clay) & 0.71 & Brown to black \\
\hline $8-2-2,17-19$ & Short segment of black vein fill & 0.92 & Dark brown \\
\hline $15-3-3,90-93$ & 2 bulbous inner-vug linings (over clay) & $0.01-0.02$ & Black \\
\hline $15-3-3,105-109$ & 2 bulbous inner-vug linings (over clay) & $0.11-0.33$ & $\begin{array}{l}\text { Dark brown } \\
\text { to black }\end{array}$ \\
\hline $20-4-8,56-59$ & 4 patches "suspended" in phillipsite veins & $0.85-1.0$ & $\begin{array}{l}\text { Dark brown } \\
\text { to black }\end{array}$ \\
\hline
\end{tabular}

acalculated from partial microprobe analyses

(2) indicate that $\mathrm{Na}$ is more abundant than $\mathrm{K}$, and $\mathrm{Ca}$ is practically absent. $\mathrm{Na} 2 \mathrm{O} / \mathrm{K}_{2} \mathrm{O}$ varies from 1 to 4 in seven analyses but these values are only semiquantitative because of poor sample stability. Phillipsites dehydrated and crumbled in the probe chamber even without being exposed directly to the beam.

No other zeolites have been identified.

\section{Calcite}

Calcite is ubiquitous throughout the hole as vein and vug fills. It is usually present as subspherical pointed masses with grainy surfaces. In thin section, the masses display a diffuse wavy extinction suggestive of broadly radial structure (Plate 3, Figure 3). Several calcite "bulbs", display an apparently biaxial conoscopic figure. Another form of calcite which is often found in veins is coarse to fine granular (Plate 3, Figures 1, 2, 4, 5).

Magnesium contents of calcites were determined by $\mathrm{X}$-ray diffraction from the shift in the 104 (211) peak (see Table 4). The calculated compositions range from $\mathrm{Mg}_{2}$ to $\mathrm{Mg}_{8}$ with most falling between $\mathrm{Mg}_{5}$ and $\mathrm{Mg}_{7}$. There does not appear to be any systematic variation with depth in the

TABLE 4

Magnesium Contents of Some Calcites

\begin{tabular}{llc}
\hline $\begin{array}{c}\text { Sample } \\
\text { (Interval in cm) }\end{array}$ & \multicolumn{1}{c}{ Calcite Description } & $\begin{array}{c}\text { mole } \% \mathrm{MgCo}_{3} \\
(+.3)\end{array}$ \\
\hline $7-1-12,145-147$ & Vug fills in gray zone & 3.7 \\
$7-1-12,142-144$ & Vein center & 5.0 \\
$7-2-4,34-36$ & Vein center & 6.3 \\
$7-2-9,96-98$ & Vein center-bulbous first phase (see text) & 7.8 \\
$7-2-9,96-98$ & Vein fill-fibrous second phase & 5.1 \\
$8-2-2,17-19$ & Vug fills in gray zone & 6.3 \\
$15-3-3,90-93$ & Bulbs in vug & 4.7 \\
$15-3-3,105-109$ & Bulbs in vug & 6.3 \\
$16-2-11,134-142$ & Bulbs in vein center & 6.7 \\
$20-2-9,130-135$ & Vein center & 2.0 \\
$23-1-1,3-5$ & Bulbs in vug (with aragonite) & 6.3 \\
$23-1-2,8-11$ & Bulbs in vug in green-gray zone & 6.7 \\
$23-1-2,8-11$ & Thin vein & 6.2 \\
$23-1-3,14-16$ & Bulbs in vug in brown zone & 6.0 \\
\hline
\end{tabular}
${ }^{\mathrm{a} C a l c u l a t e d}$ from shift of $104 \mathrm{X}$-ray peak assuming $\frac{1 \text { mole \% } \mathrm{MgCo}_{3}}{0.003 \mathrm{~A} \text { shift. }}$ core, or between various units. The only observed evolutionary trend is from the reopened vein in Sample 7-2, $96-98 \mathrm{~cm}$ (9). The presumed first phase (bulbous) calcite has a higher $\mathrm{Mg}$ content than the fibrous second phase. It is possible that there are variations within single fills or even single bulbs but these were not detected.

A carbonate (probably calcite as it is sometimes contiguous with calcite bulbs) often locally replaces plagioclase, and in Core 23 , olivine is replaced by a carbonate.

\section{Aragonite}

Aragonite has been identified in two samples (15-3, $89-91 \mathrm{~cm}[3 \mathrm{~A}]$ and $23-1,124-126 \mathrm{~cm}$ [20]). In both, it occurs as arrays of acicular crystals up to $1 \mathrm{~cm}$ long. In Sample $15-3,89-91 \mathrm{~cm}(3 \mathrm{~A})$, aragonite is a central vug fill after clay and Fe-Mn oxides. In Sample 23-1, 124-126 cm (20), it lies on top of a phillipsite crust in a partially filled crack.

\section{Sulfide}

Large blocky masses of reddish brown Fe-hydroxides have been found attached to the walls of both vesicles and miaroles in all units. On the basis of the microscope observation of relict sulfides contained in one such mass in Sample 7-1, 145-147 cm (12), these masses are interpreted as pseudomorphs of euhedral (octahedral) secondary pyrite crystals, which formed early in the alteration sequence, and were oxidized even in the gray zones by later alteration stages.

\section{Opaque Mineral Petrography}

Opaque-phase identification and textural features were studied by reflected light microscopy using oil immersion and magnification up to 1250 diameters. The composition of the opaque phases are unknown since the small grain-size magnetite forbade any detailed chemical analysis by electron microprobe techniques. This fact also precludes the possibility of identification of the magnetite alteration products.

In the next section we describe the four groups of opaque phases present: magnetite, ilmenite, sulfides, and other phases. Table 5 summarizes the mineralogy of each specimen.

The correlation between opaque phases and magnetic properties of these basalts is discussed by Honnorez et al. (this volume).

\section{Magnetite}

Three types of magnetite crystals are observed in the basalts from Hole 396B:

1) The most abundant opaque phase in the samples that we have studied is an extremely fine grained skeletal to anhedral magnetite which ranges in size from $5 \mu \mathrm{m}$ down to the limit of visibility $(0.5 \mu \mathrm{m})$.

2) Occasional larger skeletal grains of magnetite (besides the fine-grained magnetite) widespread in the groundmass occur in Sample 4-1, 103-105 cm (9); their size reaches up to $25 \mu \mathrm{m}$. In Sample $15-3,90-93 \mathrm{~cm} \mathrm{(3A),} \mathrm{the} \mathrm{most}$ 
TABLE 5

Opaque Mineralogy Summary

\begin{tabular}{|c|c|c|c|c|}
\hline $\begin{array}{c}\text { Sample } \\
\text { (Interval in } \mathrm{cm} \text { ) }\end{array}$ & $\begin{array}{l}\text { Rock } \\
\text { Color }\end{array}$ & $\begin{array}{l}\text { Magnetite } \\
\text { (Description, Grain Size) }\end{array}$ & $\begin{array}{l}\text { Sulfides } \\
\text { (Description, Grain Size) }\end{array}$ & Other Phases \\
\hline $4-1-1,14-17$ & Brown & Oxide-free glass & $\begin{array}{l}\text { Two large sulfide spherules: } \mathrm{Cb}(?) \text {, } \\
\mathrm{Mw}(?) \text { and } \mathrm{S} 1(?) \text { assemblage; par- } \\
\text { tial alteration into Fe-hydroxides }\end{array}$ & Mixed Fe-hydroxides \\
\hline $4-1-2,22-24$ & Brown & $\begin{array}{l}\text { Extremely fine anhedral grains, } \\
\text { light brown to off-white color and } \\
\text { red-yellow IR ( } 2 \mu \mathrm{m} \text { or less); } \\
\text { occasional larger euhedral to sub- } \\
\text { hedral tan grains, some are mantled } \\
\text { with HEM }(10 \mu \mathrm{m})\end{array}$ & $\begin{array}{l}\text { Scarce small indet. rounded grains } \\
(\leqslant .5 \mu \mathrm{m})\end{array}$ & \\
\hline $4-1-9,103-105$ & Gray & $\begin{array}{l}\text { Abundant fine skeletal grains, } \\
\text { light } \tan \text { to off-white; some red or } \\
\text { red-yellow IR ( } 5 \mu \mathrm{m} \text { or less); } \\
\text { occasional euhedral medium- } \\
\text { brown grains ( } 10 \text { to } 15 \mu \mathrm{m}) \text {, few } \\
\text { with gray core of chrome-spinel(?) }\end{array}$ & $\begin{array}{l}\text { Frequent small spherules of sul- } \\
\text { fides }(\leqslant 2 \mu \mathrm{m}) \text {; few irregular } \\
\text { grains of Po in association with } \\
\text { euhedral magnetite }(10 \mu \mathrm{m})\end{array}$ & $\begin{array}{l}\text { Chrome-spinel(?) } \\
\text { Ilm.(?) }\end{array}$ \\
\hline $4-2-9,62-64$ & Brown & $\begin{array}{l}\text { Extremely fine anhedral grains, } \\
\text { light tan to off-white and red- } \\
\text { yellow IR }(1.5 \mu \mathrm{m} \text { or less); } \\
\text { occasional medium brown euhe- } \\
\text { dral grains }(\leqslant 10 \mu \mathrm{m})\end{array}$ & $\begin{array}{l}\text { Occasional two-phase irregular } \\
\text { grains of } \mathrm{Cb}(?) \text { with } \mathrm{Cp} \text { blebs; } \\
\text { associated grains of magnetite }\end{array}$ & $\begin{array}{l}\text { One ovoidal grain } \\
\text { of chrome-spinel } \\
\text { similar phase } \\
(100 \mu \mathrm{m})\end{array}$ \\
\hline $5-1-9,86-88$ & Gray & $\begin{array}{l}\text { Extremely fine skeletal to anhe- } \\
\text { dral grains, light tan to off- } \\
\text { white and red-yellow IR ( } 3 \mu \mathrm{m} \\
\text { or less). }\end{array}$ & & \\
\hline $5-2-2,12-14$ & Brown & $\begin{array}{l}\text { Extremely fine skeletal to anhe- } \\
\text { dral grains, off-white color and } \\
\text { yellow reddish IR ( } 2 \mu \mathrm{m} \text { or less) }\end{array}$ & $\begin{array}{l}\text { Scarce anhedral grains of one and } \\
\text { two phases yellow sulfides (Po and } \\
\text { Cp?); size range from } 15 \mu \mathrm{m} \text { to } \\
3 \mu \mathrm{m} \text {. }\end{array}$ & \\
\hline $5-2-4,28-31$ & $\begin{array}{l}\text { Gray } \\
\text { to } \\
\text { Brown }\end{array}$ & $\begin{array}{l}\text { Extremely fine anhedral grains } \\
(\leqslant 1 \mu \mathrm{m}) ; \text { occasional larger euhe- } \\
\text { dral medium tan grains (up to } \\
10 \mu \mathrm{m}) \text { with adjacent spherules } \\
\text { of Py(?) }\end{array}$ & Scarce indet. rounded grains $(\leqslant 2 \mu \mathrm{m})$ & \\
\hline $5-2-5,32-24$ & Gray & $\begin{array}{l}\text { Fine skeletal and anhedral grains, } \\
\text { light tan to white-off color and } \\
\text { red to red-yellow IR }(\leqslant 7 \mu \mathrm{m})\end{array}$ & & $\operatorname{Ilm}(?)$ \\
\hline $6-1-7,55-57$ & Gray & $\begin{array}{l}\text { Fine skeletal to anhedral grains, } \\
\text { light tan to off-white, red to } \\
\text { red-yellow IR }(\leqslant 5 \mu \mathrm{m}) \text {; occas- } \\
\text { ional larger subhedral grains, } \\
\text { medium tan and lightening of } \\
\text { the edges }(15 \text { to } 18 \mu \mathrm{m})\end{array}$ & & $\begin{array}{l}\text { Lath-shape grains } \\
\text { of oxidized } \operatorname{llm}(?) \text {, } \\
\text { red IR }\end{array}$ \\
\hline $6-1-14,109-111$ & Brown & $\begin{array}{l}\text { Extemely fine anhedral grains } \\
\text { off-white color }\end{array}$ & & \\
\hline $7-1-12,142-144$ & $\begin{array}{l}\text { Gray } \\
\text { to } \\
\text { brown }\end{array}$ & $\begin{array}{l}\text { Fine skeletal to anhedral grains, } \\
\text { mostly off-white color and red- } \\
\text { yellow IR }(\leqslant 5 \mu \mathrm{m}) \text {; few larger } \\
\text { euhedral tan grains ( } 10 \text { to } \\
40 \mu \mathrm{m}) \text {. }\end{array}$ & $\begin{array}{l}\text { Very scarce rounded indet. } \\
\text { grains }(2 \mu \mathrm{m})\end{array}$ & \\
\hline $7-2-4,34-36$ & Brown & $\begin{array}{l}\text { Extremely fine anhedral grains, } \\
\text { off-white color and orange- } \\
\text { yellow IR }(\leqslant 2 \mu \mathrm{m})\end{array}$ & $\begin{array}{l}\text { Spherule of Cp partly oxidized } \\
\text { into Fe-hydroxide ( } 40 \mu \mathrm{m} \text { across) }\end{array}$ & \\
\hline $7-2-5,47-49$ & Brown & $\begin{array}{l}\text { Extremely fine anhedral grains, } \\
\text { off-white color }(\leqslant 1.5 \mu \mathrm{m})\end{array}$ & $\begin{array}{l}\text { Few irregular masses of } \mathrm{Cp}(?) \text { in } \\
\text { the groundmass and one such } \\
\text { grain inside narrow vein (grain } \\
\text { size up to } 10 \mu \mathrm{m} \text { ) }\end{array}$ & \\
\hline $7-2-9,96-98$ & Brown & $\begin{array}{l}\text { Fine skeletal to anhedral grains, } \\
\text { off-white color and some red- } \\
\text { yellow IR }(\leqslant 1 \mu \mathrm{m}) \text {. }\end{array}$ & $\begin{array}{l}\text { Scarce rounded indet. grains } \\
(\leqslant 1.5 \mu \mathrm{m})\end{array}$ & \\
\hline
\end{tabular}


TABLE 5 - Continued

\begin{tabular}{|c|c|c|c|c|}
\hline $\begin{array}{l}\text { Sample } \\
\text { (Interval in } \mathrm{cm} \text { ) }\end{array}$ & $\begin{array}{l}\text { Rock } \\
\text { Color }\end{array}$ & $\begin{array}{c}\text { Magnetite } \\
\text { (Description, Grain Size) }\end{array}$ & $\begin{array}{c}\text { Sulfides } \\
\text { (Description, Grain Size) }\end{array}$ & Other Phases \\
\hline $8-1-8 A, 62-64$ & Gray & $\begin{array}{l}\text { Abundant fine skeletal to anhe- } \\
\text { dral grains, medium tan to off- } \\
\text { white color and red to red-yellow } \\
\text { IR }(5 \mu \mathrm{m} \text { or less); occasional } \\
\text { euhedral to subhedral grains, med- } \\
\text { ium tan color }(20 \mu \mathrm{m} \text { to } 25 \mu \mathrm{m}) \text {; } \\
\text { Hem fringe on some euhedral Mt }\end{array}$ & $\begin{array}{l}\text { Frequent rounded indet. grains } \\
(\leqslant 1.5 \mu \mathrm{m}) \text {; relicts of } \mathrm{CP}(?)\end{array}$ & $\begin{array}{l}\text { Occasional lath- } \\
\text { shape Ilm(?) } \\
\text { grains; Hem } \\
\text { growths on } \mathrm{Mt} \text {; } \\
\text { Frequent devel- } \\
\text { opment of Fe-hy- } \\
\text { droxides with } \\
\text { relicts of Cp(?) }\end{array}$ \\
\hline $8-1-13,118-120$ & $\begin{array}{l}\text { Gray } \\
\text { to } \\
\text { brown }\end{array}$ & $\begin{array}{l}\text { Extremely fine skeletal to anhe- } \\
\text { dral grains, off white-color and } \\
\text { red-yellow IR }(\leqslant 2 \mu \mathrm{m}) \text {; occasional } \\
\text { larger euhedral grains (up to } 6 \mu \mathrm{m}) \text {, } \\
\text { medium tan color }\end{array}$ & Very scarce indet. grains & \\
\hline $8-1-13,118-120$ & Brown & $\begin{array}{l}\text { Most opaques are broken down, } \\
\text { but occasional small anhedral } \\
\text { grains remain }\end{array}$ & & \\
\hline $8-1-16,145-149$ & Brown & $\begin{array}{l}\text { Extremely fine anhedral grains, } \\
\text { off-white color and red-yellow IR } \\
(\leqslant 2 \mu \mathrm{m}) \text {; occasional euhedral tan } \\
\text { grains with lighter margins (up to } \\
12 \mu \mathrm{m})\end{array}$ & & \\
\hline $8-2-2,17-19$ & $\begin{array}{l}\text { Gray } \\
\text { to } \\
\text { brown }\end{array}$ & $\begin{array}{l}\text { Gray rock: abundant skeletal } \\
\text { grains, color vaires from medium } \\
\text { to light } \tan (3 \text { to } 10 \mu \mathrm{m}) \text {; brown } \\
\text { rock: oxides are partially or } \\
\text { totally broken down }\end{array}$ & $\begin{array}{l}\text { Occasional isolated or } \\
\text { clustered rounded indet. } \\
(\leqslant 2 \mu \mathrm{m})\end{array}$ & \\
\hline $15-3-3 \mathrm{~A}, 90-93$ & & $\begin{array}{l}\text { Abundant skeletal to anhedral tan } \\
\text { grains, some with dark brown } \\
\text { spinel rodlets parallel to }(001) \\
\text { planes; color lightening toward the } \\
\text { grain boundaries ( } 20 \text { to } 40 \mu \mathrm{m}) ; \\
\text { occasional euhedral tan grains }(20 \\
\mu \mathrm{m}) \text { with chrome spinel inclusion. }\end{array}$ & $\begin{array}{l}\text { Few irregular masses of indet. } \\
\text { phase with chrome spinel grains } \\
\text { included }\end{array}$ & $\begin{array}{l}\text { Chrome spinel } \\
\text { rounded grains } \\
(5 \mu \mathrm{m}) \text { Masses } \\
\text { of dull Fe-hydrox- } \\
\text { ides surrounding } \\
\text { sulfide relicts }\end{array}$ \\
\hline $20-2-5 A, 51-53$ & Gray & $\begin{array}{l}\text { Abundant fine skeletal to anhedral } \\
\text { grains, light tan to off-white and } \\
\text { red to red-yellow IR }(\leqslant 5 \mu \mathrm{m}) ; \\
\text { occasional subhedral to euhedral } \\
\text { grains, medium tan color ( } 10 \text { to } \\
20 \mu \mathrm{m}) ; \text { chrome-spinel inclusion } \\
\text { and Hem fringe are commonly } \\
\text { associated with this euhedral Mt }\end{array}$ & $\begin{array}{l}\text { Occasional rounded indet. grains } \\
(\leqslant 1.5 \mu \mathrm{m}) \text {; one anhedral grain of } \\
\mathrm{Bn}+\mathrm{Cp} \text { partially oxidized to } \mathrm{Cr} \\
(8 \mu \mathrm{m})\end{array}$ & $\begin{array}{l}\text { Very small chrome } \\
\text { spinel(?) grains in- } \\
\text { cluded in sulfide } \\
\text { relicts Ilm(?) }\end{array}$ \\
\hline $20-2-9 \mathrm{~F}, 130-135$ & Brown & $\begin{array}{l}\text { Oxides are partly broken down; } \\
\text { remaining anhedral grains, tan to } \\
\text { off-white color and red-yellow IR } \\
(\leqslant 2 \mu \mathrm{m}) \text {; occasional subhedral } \\
\tan \text { grains ( } 4 \text { to } 7 \mu \mathrm{m})\end{array}$ & $\begin{array}{l}\text { Two spherules of } \mathrm{Cp}+\text { Po par- } \\
\text { tially oxidized to Fe-hydroxide } \\
\text { and } \mathrm{Cv}(50 \mu \mathrm{m} \text { across); irregular } \\
\text { mass of } \mathrm{Cb}(?) \text { with } \mathrm{Cp} \text { blebs } \\
(120 \mu \mathrm{m} \text { across) }\end{array}$ & $\begin{array}{l}\text { Euhedral grains of } \\
\text { chrome spinel en- } \\
\text { closed in plagio- } \\
\text { clase }(50 \text { to } 100 \mu \mathrm{m})\end{array}$ \\
\hline $23-1-1,3-5$ & Green & $\begin{array}{l}\text { Fine anhedral grains are light } \\
\text { brown }(\leqslant 5 \mu \mathrm{m}) \text {; larger skeletal } \\
\text { grains occur occasionally (up } \\
\text { to } 30 \mu \mathrm{m})\end{array}$ & $\begin{array}{l}\text { Two spherules of } \mathrm{Cb}(?) \text { with } \\
\mathrm{Cp}(?) \text { blebs }(10 \text { to } 30 \mu \mathrm{m})\end{array}$ & \\
\hline $23-1-2,8-11$ & Green & $\begin{array}{l}\text { Abundant fine anhedral grains, } \\
\text { light brown }(\leqslant 5 \mu \mathrm{m}) \text {; occasional } \\
\text { larger skeletal to euhedral grains, } \\
\text { medium brown color ( } 15 \text { to } \\
25 \mu \mathrm{m})\end{array}$ & $\begin{array}{l}\text { One irregular grain of } \mathrm{Cp}(?) \text { with } \\
\text { exsolved flame-like bodies of } \\
\text { Mw(?) ( } 80 \mu \mathrm{m} \text { across) }\end{array}$ & $\begin{array}{l}\text { Fe-hydroxide are } \\
\text { lining thin vein walls } \\
\text { or filling them; } \\
\text { orange-red IR } \\
\text { are common }\end{array}$ \\
\hline $23-1-4,18-24$ & Green & $\begin{array}{l}\text { Fine anhedral grains, light brown } \\
(\leqslant 4 \mu \mathrm{m}) \text {; larger skeletal and euhe- } \\
\text { dral grains occur occasionally }\end{array}$ & & \\
\hline
\end{tabular}

Opaque Mineralogy Summary: $\mathrm{Bn}=$ Bornite, $\mathrm{Cb}=$ Cubanite, $\mathrm{Cp}=$ Chalcopyrite, $\mathrm{Cv}=\mathrm{Covellite}$, Hem $=$ Hematite. Note: $\mathrm{Ilm}=$ Ilmenite, $\mathrm{IR}=$ Internal Reflections, $\mathrm{Mw}=$ Mackinawite, Po $=$ Pyrrhotite, $\mathrm{SI}=$ Sphalerite. 
abundant magnetite occurs as skeletal crystals, ranging in size from 20 to $40 \mu \mathrm{m}$.

3) Another type of magnetite occurs in several specimens; anhedral to subhedral and euhedral forms concentrate around or near miarolitic voids. Their size ranges from 10 to $40 \mu \mathrm{m}$ (Plate 5, Figure 1).

\section{Units 1 and 2}

The fine anhedral and skeletal magnetite (type 1) is widespread in the groundmass of the gray zones, but it has been partially to completely destroyed in many of the brown samples. The color of this magnetite frequently displays a light $\tan$ to off-white shade, which is characteristically related with the degree of alteration of the specimen; the more altered the rock, the lighter is the color of the magnetite and the higher its reflectivity. Moreover, red to red-yellow internal reflections are often recognized. Ade-Hall (1976) describes grains of magnetite which show similar lightening in color but he refers to a red-staining of the surrounding silicates. According to Ade-Hall these two features of the magnetite are the products of low temperature oxidation.

Occasional larger skeletal forms of magnetite (type 2) are scattered in the groundmass of Sample 4-1, 103-105 cm (9). They display a homogeneous medium brown color at the center which grades into lighter brown towards the edges. A few volume change cracks are commonly present in the rims of the grains. A core of chrome-spinel was observed which grades into the surrounding magnetite (Plate 5, Figure 2).

Large subhedral or euhedral grains of magnetite (type 3) are frequently found around miarolitic voids in both gray and brown samples. This magnetite is homogeneous, medium brown in color with frequent lightening toward the edge of the grain; no volume change cracks are observed. A thin mantle of hematite is present around several of these crystals of magnetite, which otherwise look fresh.

\section{Unit 3}

One specimen from Unit 3, Sample 15-3, 90-93 cm (3A), contains large skeletal magnetite (Type 2) ranging in size from 20 to $40 \mu \mathrm{m}$. Few of those grains show exsolution of a dark brown spinel parallel to the (100) planes of the host. Otherwise, magnetite displays homogeneous medium brown color. Lightening of the outer parts of the grains occasionally occurs. The already mentioned euhedral crystals of magnetite (type 3 ), described in Unit 1, are also observed here; a few of them contain a small grain of chrome spinel, symmetrically or asymmetrically included and grading into the surrounding magnetite.

\section{Unit 4}

Three samples $(20-2,51-53 \mathrm{~cm}[5 \mathrm{~A}], 20-2,94-96 \mathrm{~cm}$ [9A], and 20-2, 130-135 cm [9F]) have been studied with the microscope. The first specimen (gray rock) contains fine skeletal grains of magnetite ( $5 \mu \mathrm{m}$ or less in size) which are widespread in the groundmass; their color varies from light brown to off-white. Red-yellow internal reflections(?) are commonly seen in the smallest grains. Brown rock Samples 20-2, 94-96 cm (9A) and 20-2, 130-135 cm (9F) contain finer magnetite relicts ( $2 \mu \mathrm{m}$ or less); the grains are mainly anhedral and yellow-red internal reflections(?) are common.
In all three specimens, subhedral to anhedral crystals of homogeneous medium brown magnetite are found sporadically (Type 3). The grain size of this type of magnetite in Sample 20-2, 51-53 cm (5A) ranges from 12 to $40 \mu \mathrm{m}$, whereas, in Samples 20-2, 94-96 cm; $130-135 \mathrm{~cm}$ (9A, F), grains no larger than $7 \mu \mathrm{m}$ are observed. As described in Unit 1, this type of magnetite is also occasionally mantled by a fringe of hematite (Plate 5, Figure 3).

\section{Unit 5}

The three Unit 5 specimens which were studied, i.e., Samples 23-1, 3-5 cm (1); 23-1, 8-11 cm (2); and 23-1, $18-24 \mathrm{~cm}(4)$, contain fine anhedral grains of light brown magnetite from $5 \mu \mathrm{m}$ down to the limit of visibility. In all three, larger skeletal to subhedral forms are observed concentrated in the places where silicates of the groundmass had also grown larger. The size of these grains ranges between 15 and $25 \mu \mathrm{m}$, and their color is medium brown. Lightening of the outer part of these larger grains is observed in the gray-greenish areas in Sample 23-1, 8-11 $\mathrm{cm}$ (2); in the brown areas of this specimen, no color contrast is detected.

\section{Ilmenite}

Ilmenite is absent in most of the samples. In a few samples $(4-1,103-105 \mathrm{~cm}[9] ; 5-2,32-34 \mathrm{~cm}[5] ; 6-1$, $55-57 \mathrm{~cm}[7] ; 8-1,62-64 \mathrm{~cm}[8 \mathrm{~A}] ;$ and $20-2,51-53 \mathrm{~cm}$ $[5 \mathrm{~A}])$, lath shaped discrete grains are occasionally found the color of which is similar to that of ilmenite. However, no anisotropy is observed (Plate 5, Figure 4).

\section{Sulfides}

Different phases of sulfides are present in these basalts but they are never quantitatively important.

Primary spherules of a yellow sulfide (pyrite?) are widespread in the groundmass, isolated from or adjacent to the fine-grained skeletal magnetite; their size never exceeds $3 \mu \mathrm{m}$.

In a few samples, such as 4-2, 57-59 cm (9); 15-3, 90-93 $\mathrm{cm}(3 \mathrm{~A}) ; 20-2,51-53 \mathrm{~cm}(5 \mathrm{~A})$; and 20-2, 130-135 cm (9F), one or two irregular masses of sulfides are partially oxidized into iron hydroxides. In Sample 15-3, 90-93 cm (3A), relicts of a yellow sulfide (badly polished) are surrounded by iron hydroxides with botryoidal texture. Enclosed in this sulfide area, are small grains ( $5 \mu \mathrm{m}$ across) of a dark brown-gray phase which looks like chrome spinel. In Sample $20-2,51-53 \mathrm{~cm}$ (5A), two small irregular grains of bornite are associated to chalcopyrite and partly oxidized to covellite. Samples 4-2, 57-59 cm (9) and 20-2, 130-135 cm (9F) contain occasional irregular masses (120 to $250 \mu \mathrm{m}$ across) of a creamy yellow sulfide (cubanite?) in which small blebs of a more yellow phase (chalcopyrite?) are exsolved. Relicts of magnetite are found together with the sulfides.

Large spherules of two or more sulfide phases are observed in brown rock Samples 4-1, 14-17 cm (1) and 20-2, 130-135 cm (9F); their diameter ranges between 55 and $95 \mu \mathrm{m}$. In Sample 4-1, 14-17 cm (1), two such large spherules consist of four phases, which optically could be described as cubanite, chalcopyrite, mackinawite, and 
sphalerite. The two last phases occur as flame-like oriented bodies and small rounded grains, respectively, included in the spherules which are made up of the first two sulfides. Iron hydroxide partly replaces the spherules. In Sample 20-2, 130-135 cm (9F), a two-phase sulfide spherule, 50 $\mu \mathrm{m}$ across, consists of pyrrhotite and chalcopyrite. These sulfides are partially oxidized into iron hydroxide and covellite, respectively.

\section{Other Phases}

In Sample 20-2, 94-96 cm (9A), occasional large euhedral crystals of chrome spinel (50 to $160 \mu \mathrm{m}$ across) are associated with plagioclase phenocrysts. When those crystals are partially or totally included in the plagioclase, they are slightly rounded. Their color is medium gray, and light brown-yellow internal reflections are common. One such grain, which is not included in plagioclase but isolated in the groundmass, has not been rounded and is partially mantled by hematite.

There are several areas in gray rock Sample 20-2, 51-53 $\mathrm{cm}(5 \mathrm{~A})$ in which a fine fibroradial material had developed. This phase has moderate to low reflectivity but bireflectance and anisotropism are strong. These optical characteristics fit with those of todorokite, a manganese oxide which has been detected with X-ray diffraction.

Iron hydroxides occur occasionally and are associated mainly with altered sulfides and some veins of secondary minerals.

\section{BULK ROCK GEOCHEMISTRY}

The samples which have been chemically analyzed were selected aboard ship on the basis of their color. As often as possible, pairs of adjacent samples which exhibit brown and gray colors were selected from the same core fragment. The samples displaying a brown color are obviously altered, but the gray ones appear unaltered. However, our study proves that even these gray samples are oxidized and hydrated.

Homogeneous samples displaying a uniform color, either gray or brown, were isolated by sawing and grinding off the parts with other colors and the veins of secondary minerals. Samples were then ground in acetone, in agate mortar. A series of samples (marked with "W"' in Table 6) have been washed twice with distilled water in an ultrasonic cleaner for one hour each time, then centrifuged and dried at temperatures of less than $50^{\circ} \mathrm{C}$. The remainder of the samples (marked unw) were not treated in this way. Three samples were split and prepared both washed and unwashed before being analyzed. The analyses were indistinguishable within the analytical precision and showed that the washing process did not cause significant chemical changes.

The major, minor, and trace elements have been analyzed in bulk rock samples (after the usual grinding and homogenization in agate mortar) by the following techniques:

1) $\mathrm{SiO}_{2}$ by the classical gravimetric method

2) $\mathrm{Al}_{2} \mathrm{O}_{3}, \mathrm{TiO}_{2}$ total $\mathrm{Fe}_{2} \mathrm{O}_{3}, \mathrm{MgO}, \mathrm{CaO}, \mathrm{Na}_{2} \mathrm{O}, \mathrm{K}_{2} \mathrm{O}$, $\mathrm{Cu}, \mathrm{Zn}, \mathrm{Rb}$, and $\mathrm{Sr}$ by atomic absorption (Perkin-Elmer 303 atomic absorption spectrometer). $\mathrm{K}$ was analyzed using cesium as ionization control buffer.

3) $\mathrm{FeO}$ by titration with potassium dichromate

4) $\mathrm{P}_{2} \mathrm{O}_{5}$ by colorimetry (Hitachi 101 spectrophotometer.

5) $\mathrm{H}_{2} \mathrm{O}^{+}$and $\mathrm{CO}_{2}$ by gravimetric method using a microfurnace, using magnesium perchlorate and Ascarite as chemical traps.

TABLE 6

Bulk Sample Chemical Analyses (major elements in \%)

\begin{tabular}{|c|c|c|c|c|c|c|c|c|c|c|c|c|c|c|c|}
\hline $\begin{array}{c}\text { Sample } \\
\text { Interval } \\
\text { Prep. }\end{array}$ & $\begin{array}{c}4-1-1^{*} \\
14-17 \\
w\end{array}$ & $\begin{array}{c}4-1-2 * \\
(2) \\
22-24 \\
w\end{array}$ & $\begin{array}{l}4-2-9 \\
\text { (1) } \\
62-64 \\
\text { unw }\end{array}$ & $\begin{array}{c}4-2-9 * \\
(3) \\
57-59 \\
\\
\text { unw }\end{array}$ & $\begin{array}{l}5-2-2 \\
(3) \\
9-11 \\
\\
w\end{array}$ & $\begin{array}{c}5-2-2^{*} \\
(1,2) \\
12-14 \\
\\
W\end{array}$ & $\begin{array}{l}5-2-4 \\
28-31 \\
\text { unw }\end{array}$ & $\begin{array}{l}5-2-4^{*} \\
28-31 \\
\text { unw }\end{array}$ & $\begin{array}{l}\text { 6-1-14* } \\
109-111 \\
\text { w\& unw }\end{array}$ & $\begin{array}{c}7-1-12 \\
(1,5) \\
142-144, \\
145 \cdot 147 \\
w\end{array}$ & $\begin{array}{c}7-1-12^{*} \\
(3) \\
142-144 \\
\mathrm{w}\end{array}$ & $\begin{array}{c}7 \cdot 2-4^{*} \\
(2) \\
34-36 \\
\\
w\end{array}$ & $\begin{array}{l}7-2-5 \\
(2.4 .5) \\
47-48, \\
48-50 \\
\text { w \& unw }\end{array}$ & $\begin{array}{l}7-2-5^{*} \\
(1.3 .5) \\
47-49 \\
\text { w \& unw }\end{array}$ & $\begin{array}{l}7-2-9 \\
\text { (1) } \\
96.98\end{array}$ \\
\hline $\mathrm{SiO}_{2}$ & 47.00 & 48.10 & 48.60 & 47.70 & 50.20 & 48.00 & 50.00 & 48.00 & 47.10 & 48.00 & 47.00 & 46.00 & 48.00 & 47.00 & 50.00 \\
\hline $\mathrm{TiO}_{2}$ & 1.60 & 1.60 & 1.37 & 1.48 & 1.38 & 1.48 & 1.31 & 1.39 & 1.60 & 1.34 & 1.42 & 1.44 & 1.42 & 1.59 & 1.40 \\
\hline $\mathrm{Al}_{2} \mathrm{O}_{3}$ & 18.10 & 17.33 & 15.90 & 17.35 & 15.25 & 16.62 & 16.45 & 16.90 & 16.88 & 15.78 & 16.10 & 16.78 & 15.22 & 16.43 & 16.10 \\
\hline $\mathrm{Fe}_{2} \mathrm{O}_{3}$ & 8.50 & 6.75 & 3.05 & 6.25 & 2.76 & 6.18 & 2.37 & 6.18 & 7.60 & 3.43 & 6.48 & 7.08 & 3.29 & 7.10 & 2.72 \\
\hline $\mathrm{leO}$ & 3.44 & 4.40 & 6.56 & 4.32 & 6.96 & 4.40 & 7.04 & 4.40 & 3.85 & 6.24 & 4.72 & 4.24 & 6.62 & 4.12 & 6.72 \\
\hline $\mathrm{MnO}$ & 0.11 & 0.15 & 0.19 & 0.17 & 0.16 & 0.17 & 0.20 & 0.20 & 0.15 & 0.17 & 0.26 & 0.16 & 0.18 & 0.15 & 0.19 \\
\hline $\mathrm{MgO}$ & 3.61 & 3.48 & 7.41 & 3.36 & 7.35 & 4.35 & 7.50 & 4.57 & 3.54 & 7.96 & 4.33 & 3.51 & 7.39 & 4.30 & 7.40 \\
\hline $\mathrm{CaO}$ & 11.82 & 12.60 & 10.83 & 11.25 & 11.95 & 12.20 & 10.36 & 11.45 & 12.11 & 11.38 & 12.40 & 12.28 & 11.38 & 12.08 & 10.70 \\
\hline $\mathrm{Na}_{2} \mathrm{O}$ & 2.83 & 2.81 & 2.48 & 2.75 & 2.64 & 2.75 & 2.43 & 2.65 & 2.91 & 2.61 & 2.96 & 2.92 & 2.60 & 2.76 & 2.50 \\
\hline $\mathrm{K}_{2} \mathrm{O}$ & 0.14 & 0.19 & 0.16 & 0.18 & 0.16 & 0.26 & 0.13 & 0.23 & 0.14 & 0.19 & 0.25 & 0.27 & 0.16 & 0.17 & 0.15 \\
\hline $\mathrm{P}_{2} \mathrm{O}_{5}$ & 0.26 & 0.29 & 0.15 & 0.20 & 0.12 & 0.17 & 0.13 & 0.17 & 0.27 & 0.13 & 0.19 & 0.16 & 0.14 & 0.20 & 0.14 \\
\hline $\mathrm{H}_{2} \mathrm{O}^{+}$ & 3.40 & 2.50 & 2.20 & 3.60 & 1.30 & 3.30 & 2.00 & 3.30 & 4.30 & 2.00 & 3.40 & 2.40 & 1.65 & 2.97 & 1.50 \\
\hline $\mathrm{CO}_{2}$ & 0.40 & 0.30 & $<.1$ & 0.22 & 0.10 & 0.58 & 0.10 & 0.38 & 0.45 & 0.30 & 0.40 & 0.40 & 0.33 & 0.51 & 0.20 \\
\hline Total & 101.36 & 100.52 & 98.90 & 98.83 & 100.33 & 100.46 & 100.02 & 99.82 & 100.90 & 99.53 & 99.91 & 97.64 & 98.38 & 99.38 & 99.69 \\
\hline B & 42 & 45 & 25 & 45 & 30 & 42 & 60 & 60 & 71 & 48 & 42 & 55 & 28 & 41 & 60 \\
\hline $\mathrm{Co}$ & 24 & 44 & 33 & 35 & 44 & 48 & 30 & 30 & 30 & 69 & 30 & 47 & 43 & 42 & 30 \\
\hline $\mathrm{Cr}$ & 360 & 350 & 320 & 330 & 300 & 310 & 350 & 310 & 290 & 280 & 290 & 310 & 270 & 320 & 320 \\
\hline $\mathrm{Cu}$ & 60 & 72 & 59 & 63 & 60 & 60 & 63 & 65 & 69 & 70 & 75 & 72 & 68 & 73 & 66 \\
\hline $\mathrm{Ni}$ & 60 & 47 & 125 & 135 & 150 & 105 & 120 & 100 & 68 & 135 & 140 & 145 & 123 & 100 & 120 \\
\hline Se & 35 & 32 & 27 & 30 & 32 & 28 & 27 & 27 & 29 & 25 & 26 & 30 & 25 & 27 & 26 \\
\hline Sr & 200 & 148 & 130 & 132 & 134 & 134 & 140 & 140 & 183 & 160 & 163 & 180 & 163 & 171 & 125 \\
\hline v & 390 & 390 & 280 & 320 & 320 & 390 & 350 & 350 & 345 & 320 & 380 & 320 & 345 & 300 & 310 \\
\hline Y & 29 & 29 & 27 & 30 & 26 & 22 & 42 & 36 & 29 & 25 & 29 & 32 & 26 & 34 & 30 \\
\hline $\mathrm{Zn}$ & 100 & 97 & 74 & 82 & 78 & 82 & 72 & 78 & 91 & 80 & 92 & 82 & 84 & 85 & 73 \\
\hline $\mathrm{Zr}$ & 105 & 105 & 90 & 95 & 90 & 100 & 100 & 100 & 105 & 100 & 100 & 110 & 95 & 100 & 85 \\
\hline $\mathrm{FeO}^{*}$ & 11.09 & 10.47 & 9.30 & 9.94 & 9.44 & 9.96 & 9.17 & 9.96 & 10.69 & 9.33 & 10.55 & 10.61 & 9.58 & 10.51 & 9.17 \\
\hline$O x^{\circ}$ & 0.69 & 0.58 & 0.30 & 0.57 & 0.26 & 0.56 & 0.23 & 0.56 & 0.64 & 0.33 & 0.55 & 0.60 & 0.31 & 0.61 & 0.27 \\
\hline
\end{tabular}

Note: $*=$ brown sample, $\dagger=$ brownish gray sample, all other samples gray 
6) $\mathrm{B}, \mathrm{CO}, \mathrm{Cr}, \mathrm{Ni}, \mathrm{Sc}, \mathrm{V}, \mathrm{Y}$ and $\mathrm{Zr}$ by optical emission spectroscopy (Bausch-Lombe dual grating spectrograph).

Table 6 presents the chemical analyses of 24 bulk samples from the upper Units 1 and 2, and three samples from Unit 3 and three others from the uppermost part of Unit 5.

Figures 2 to 5 present the various chemical changes which took place in the basalts of Unit 1 because of the alteration. The various oxide contents of the gray and brown samples are plotted against their $\mathrm{H}_{2} \mathrm{O}^{+}$content and their oxidation ratio. The latter coefficient is defined as the atomic ratio of ferric iron to the total iron of each sample, and it is calculated according to the following formula:

$$
\mathrm{O}_{\mathrm{x}}^{0}=\frac{\mathrm{Fe}_{2} \mathrm{O}_{3} / 80}{\mathrm{Fe}_{2} \mathrm{O}_{3} / 80+\mathrm{FeO} / 72}
$$

A completely oxidized rock has an oxidation ratio of 1 , whereas if a basalt without $\mathrm{Fe}_{2} \mathrm{O}_{3}$ at all could exist, its oxidation ratio would be equal to zero. Assuming that the ideally fresh tholeiite from Unit 1 had a maximum $\mathrm{Fe}_{2} \mathrm{O}_{3}$ content of 1.5 per cent, the oxidation ratio of such a rock would be 0.14 .

Dots representing pairs of gray and brown zones from the same core fragments are connected by continuous tielines; the dashed line connects Samples 12-1(1) (gray) and 12-1(3) (brown).

The hatched rectangles represent the ranges of the various oxides and $\mathrm{H}_{2} \mathrm{O}^{+}$contents ratios inferred from the analyses of "fresh"' samples performed by the other contributors to this volume. When the chemical composition of the fresh glasses do not overlap completely with those of the "fresh" non-glassy rocks, two directions of hatching have been used.

Figure 2e presents the plot of the $\mathrm{H}_{2} \mathrm{O}^{+}$contents of the various samples against their oxidation ratios. The fact that these two parameters almost perfectly covary, demonstrates the well-known observation that the alteration of basaltic lavas by aqueous solutions is characterized by a hydration and an oxidation of the rock. One notes a hiatus separating gray and brown samples, between 0.34 and 0.56 values of the oxidation ratio, whereas, the $\mathrm{H}_{2} \mathrm{O}^{+}$contents of the brown and gray samples overlap from 2.5 to 3.0 per cent. One may, therefore, use either of these parameters to characterize the degree of alteration of the ridge basalts. However, the oxidation ratio appears (see below) to be a better parameter for measuring the subaquatic alteration, partly because the analytical methods used for measuring $\mathrm{FeO}$ and $\mathrm{Fe}_{2} \mathrm{O}_{3}$ contents are more accurate and reliable than that used for measuring $\mathrm{H}_{2} \mathrm{O}^{+}$.

Figures $5 \mathrm{a}$ to $5 \mathrm{f}$ show the variation with the oxidation ratio of a few selected oxides, the weight percentages of which have been normalized with respect to $\mathrm{Al}_{2} \mathrm{O}_{3}$. An average value of 15.3 per cent of $\mathrm{Al}_{2} \mathrm{O}_{3}$ was used in the calculation of the normalized contents. This figure corresponds to the average $\mathrm{Al}_{2} \mathrm{O}_{3}$ content of 77 analyses of "fresh"' basalts and glasses from Units 1 and 2 performed by the other contributors to this volume (see Dungan et al.; Robinson; Sato et al., this volume). The average $\mathrm{Al}_{2} \mathrm{O}_{3}$ contents of 30 fresh glasses is also 15.3 per cent.

From Figures 2 to 5 one can readily see the following: 1) The basalts from Unit 1 have drastically lost

TABLE 6 - Continued

\begin{tabular}{|c|c|c|c|c|c|c|c|c|c|c|c|c|c|c|}
\hline $\begin{array}{c}7-2-9 * \\
\text { (1) }\end{array}$ & $\begin{array}{c}8-1-13 \\
(2)\end{array}$ & $\begin{array}{l}8-1-13^{*} \\
(2)\end{array}$ & $\begin{array}{c}8-1-13^{*} \\
\text { (4) }\end{array}$ & $8-1-16^{*}$ & $8-2-2$ & $8-2-2^{*}$ & $12-1-1$ & $12-1-3^{*}$ & $15-2-1 \mathrm{D}+$ & 15-2-1E† & $15-2-2 C$ & $23-1-2$ & $23-1-2 \dagger$ & $23-1-4$ \\
\hline $96-98$ & $118-120$ & $118-120$ & $114-116$ & $145-149$ & $17-19$ & $17-19$ & $9-11$ & $27-29$ & $37-42$ & $42-45$ & $118-132$ & $8-11$ & $8-11$ & $18-24$ \\
\hline unw & unw & unw & unw & w & unw & unw & unw & unw & unw & unw & unw & unw & unw & unw \\
\hline 46.00 & 50.30 & 46.80 & 46.80 & 47.50 & 49.60 & 47.50 & 49.20 & 46.80 & 47.40 & 48.80 & 48.50 & 49.00 & 48.60 & 47.00 \\
\hline 1.41 & 1.50 & 1.73 & 1.76 & 1.50 & 1.47 & 1.66 & 1.43 & 1.62 & 1.80 & 1.65 & 1.75 & 1.53 & 1.73 & 1.52 \\
\hline 15.80 & 15.85 & 17.35 & 17.20 & 16.90 & 15.45 & 16.60 & 14.75 & 16.55 & 14.60 & 14.40 & 14.60 & 16.50 & 15.60 & 15.90 \\
\hline 6.05 & 3.69 & 6.86 & 7.10 & 6.27 & 3.49 & 6.25 & 3.45 & 6.99 & 5.82 & 5.79 & 3.40 & 5.30 & 5.60 & 5.56 \\
\hline 3.76 & 6.56 & 4.16 & 4.16 & 4.80 & 6.08 & 4.48 & 5.84 & 4.00 & 4.80 & 4.16 & 6.88 & 3.36 & 3.36 & 3.36 \\
\hline 0.20 & 0.21 & 0.15 & 0.16 & 0.16 & 0.18 & 0.17 & 0.17 & 0.20 & 0.17 & 0.16 & 0.17 & 0.14 & 0.13 & 0.14 \\
\hline 5.20 & 7.40 & 4.28 & 3.76 & 3.90 & 7.40 & 4.10 & 7.50 & 4.45 & 7.34 & 6.96 & 8.85 & 6.65 & 6.53 & 7.17 \\
\hline 11.45 & 10.70 & 11.80 & 11.75 & 12.55 & 11.20 & 11.72 & 10.33 & 11.55 & 10.73 & 10.94 & 10.94 & 11.04 & 12.23 & 10.90 \\
\hline 2.60 & 2.30 & 2.73 & 2.73 & 2.81 & 2.55 & 2.80 & 2.55 & 2.62 & 2.98 & 2.99 & 2.80 & 2.68 & 3.13 & 2.73 \\
\hline 0.17 & 0.12 & 0.12 & 0.14 & 0.21 & 0.22 & 0.22 & 0.23 & 0.22 & 0.26 & 0.23 & 0.22 & 0.22 & 0.23 & 0.25 \\
\hline 0.15 & 0.14 & 0.26 & 0.27 & 0.25 & 0.15 & 0.20 & 0.16 & 0.21 & 0.17 & 0.17 & 0.15 & 0.20 & 0.19 & 0.20 \\
\hline 4.60 & 1.60 & 2.40 & 2.44 & 2.25 & 1.30 & 2.85 & 2.45 & 3.60 & 4.00 & 4.17 & 1.45 & 3.50 & 3.25 & 3.60 \\
\hline 0.30 & $<.1$ & 0.35 & 0.23 & 0.25 & 0.22 & 0.35 & 0.10 & 0.10 & 0.75 & 0.12 & 0.30 & 0.55 & 0.60 & 0.54 \\
\hline 97.69 & 100.37 & 98.99 & 98.51 & 99.35 & 98.64 & 98.90 & 98.16 & 98.91 & 100.82 & 100.54 & 100.01 & 100.68 & 101.18 & 98.87 \\
\hline 50 & 70 & 60 & 70 & 50 & 35 & 50 & 70 & 52 & 40 & 45 & 40 & 55 & 35 & 50 \\
\hline 20 & 55 & 28 & 28 & 29 & 44 & 33 & 56 & $\begin{array}{l}32 \\
27\end{array}$ & 45 & 47 & 45 & 35 & 45 & 20 \\
\hline 280 & 280 & 260 & 310 & 260 & 250 & 270 & 170 & 200 & 430 & 260 & 420 & 270 & 390 & 320 \\
\hline 90 & 66 & 69 & 65 & 70 & 65 & 68 & 63 & 60 & 70 & 80 & 70 & 60 & 60 & 61 \\
\hline 105 & 120 & 90 & 75 & 70 & 120 & 95 & 130 & 85 & 130 & 130 & 140 & 105 & 120 & 130 \\
\hline 25 & 27 & 27 & 32 & 27 & 27 & 28 & 28 & 29 & 40 & 35 & 40 & 25 & 40 & 35 \\
\hline 130 & 155 & 150 & 170 & 150 & 120 & 140 & 130 & 130 & 165 & 165 & 160 & 170 & 180 & 156 \\
\hline 270 & 360 & 370 & 360 & 390 & 300 & 350 & 370 & 300 & 290 & 310 & 330 & 290 & 290 & 380 \\
\hline 23 & 25 & 30 & 22 & 30 & 30 & 22 & 22 & 33 & 49 & 40 & 40 & 24 & 35 & 20 \\
\hline 87 & 83 & 89 & 129 & 85 & 79 & 84 & 75 & 93 & 135 & 133 & 128 & 100 & 110 & 82 \\
\hline 75 & 110 & 115 & 123 & 105 & 120 & 120 & 115 & 75 & 105 & 110 & 102 & 120 & 98 & 120 \\
\hline 9.20 & 9.88 & 10.33 & 10.55 & 10.44 & 9.22 & 10.10 & 8.94 & 10.29 & 10.04 & 9.37 & 9.94 & 8.13 & 8.40 & 8.36 \\
\hline 0.59 & 0.34 & 0.60 & 0.61 & 0.54 & 0.34 & 0.56 & $\begin{array}{l}8.94 \\
0.35\end{array}$ & 0.61 & 0.52 & 0.56 & 0.31 & 0.59 & 0.60 & 0.60 \\
\hline
\end{tabular}




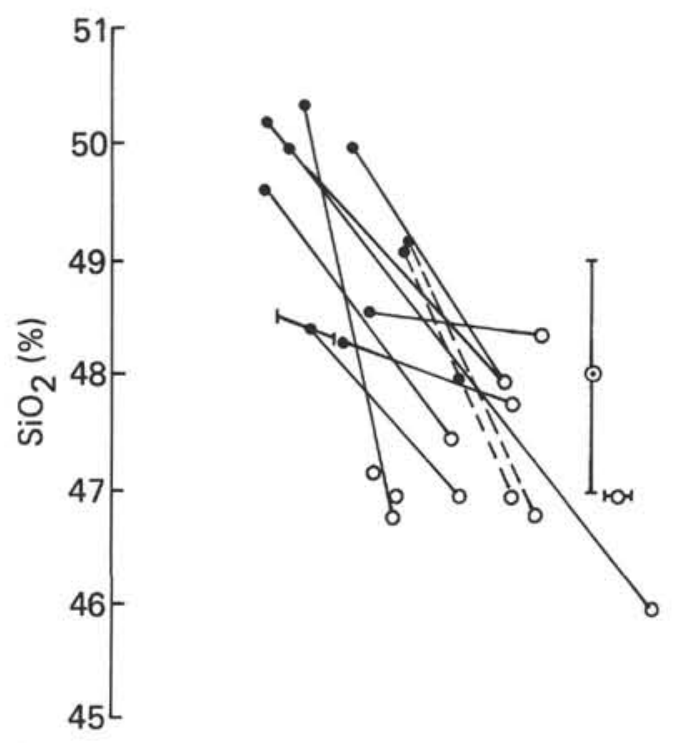

a
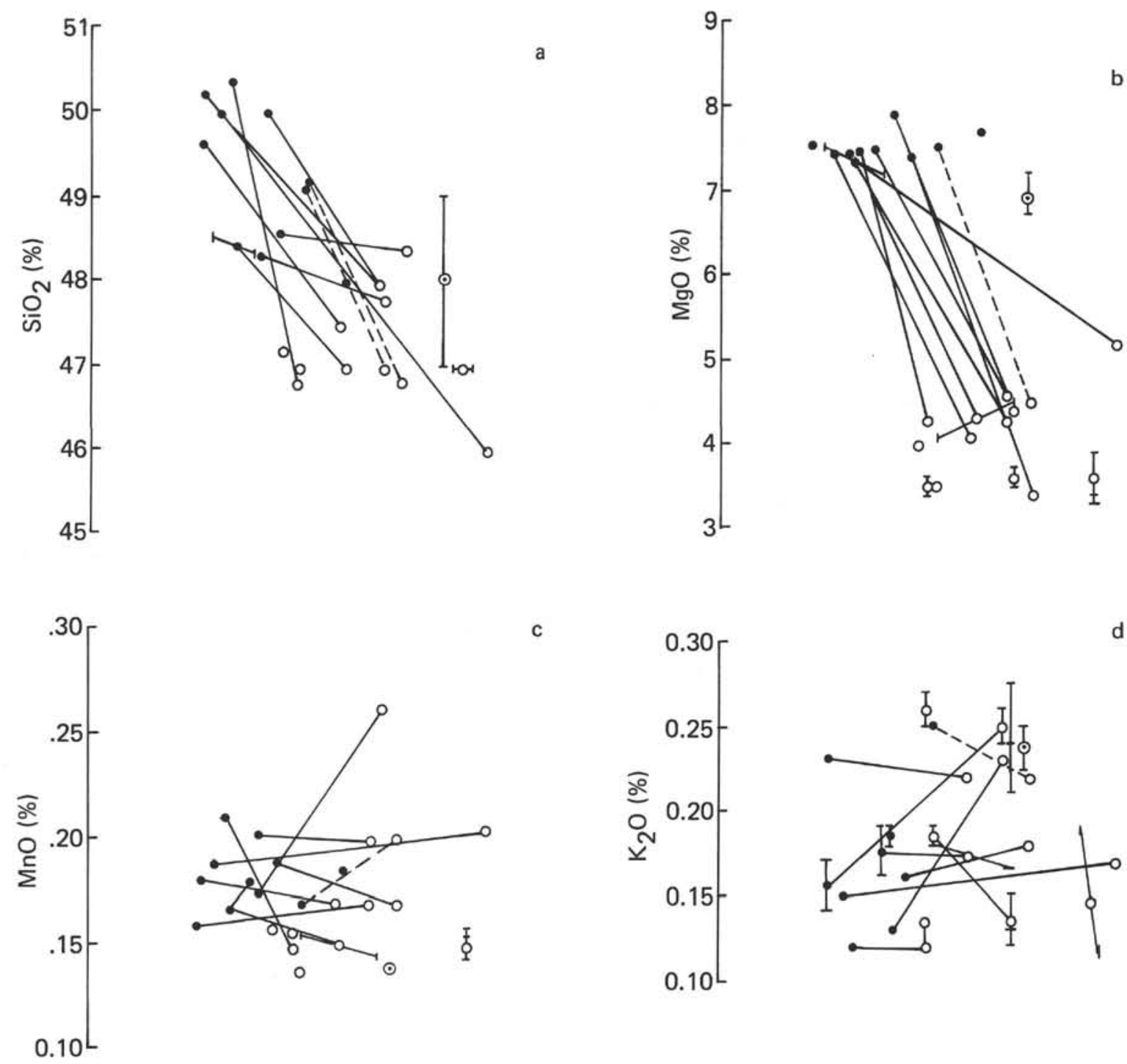

c
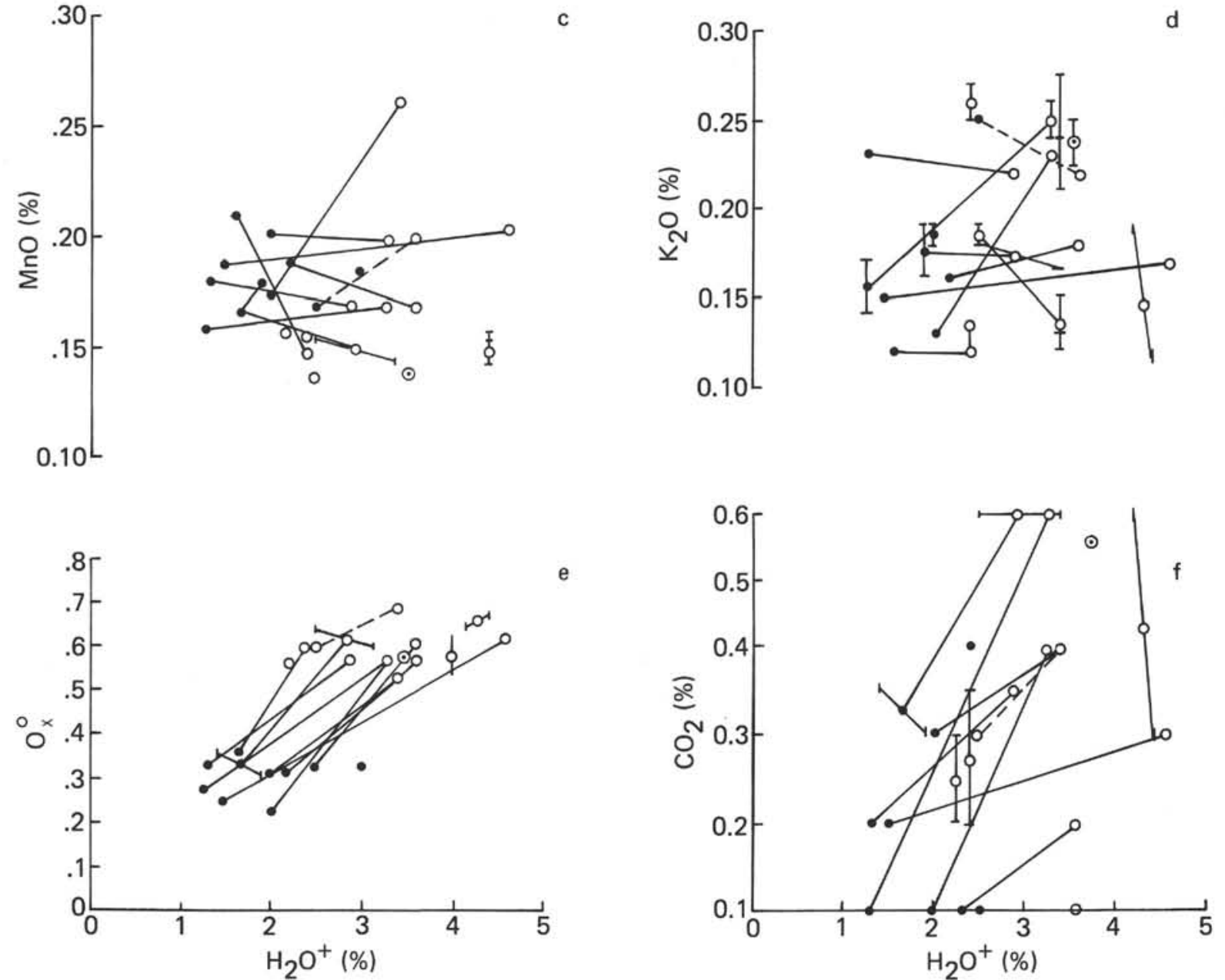

Figure 2. Bulk chemistry variations with alteration: weight oxides $v$ s. $\mathrm{H}_{2} \mathrm{O}^{+}$. Note: $\mathrm{O}=$ brown samples from Units 1 and 2. = gray samples from Units 1 and 2. = green samples from Unit $5 .-=$ pairs of contiguous gray and brown samples. --- = pairs of samples which do not come from the same core fragment. 

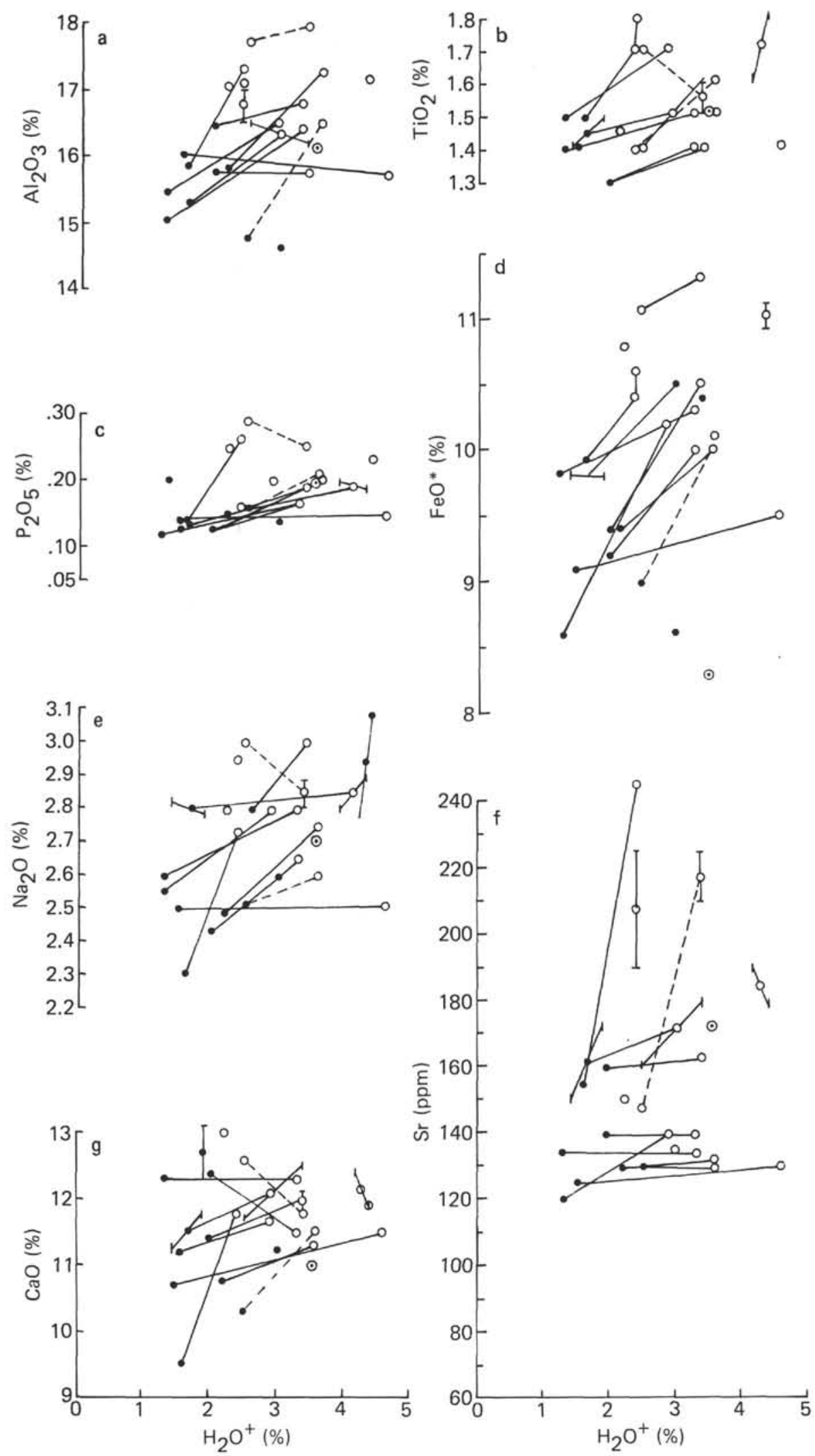

Figure 3. Bulk chemistry variations with alteration: weight oxides vs. $\mathrm{H}_{2} \mathrm{O}^{+}$. Note: $0=$ brown samples from Units 1 and $2 . \bullet=$ gray samples from Units 1 and 2. $\odot=$ green samples from Unit $5 .-=$ pairs of contiguous gray and brown samples. - - = pairs of samples which do not come from the same core fragment. 

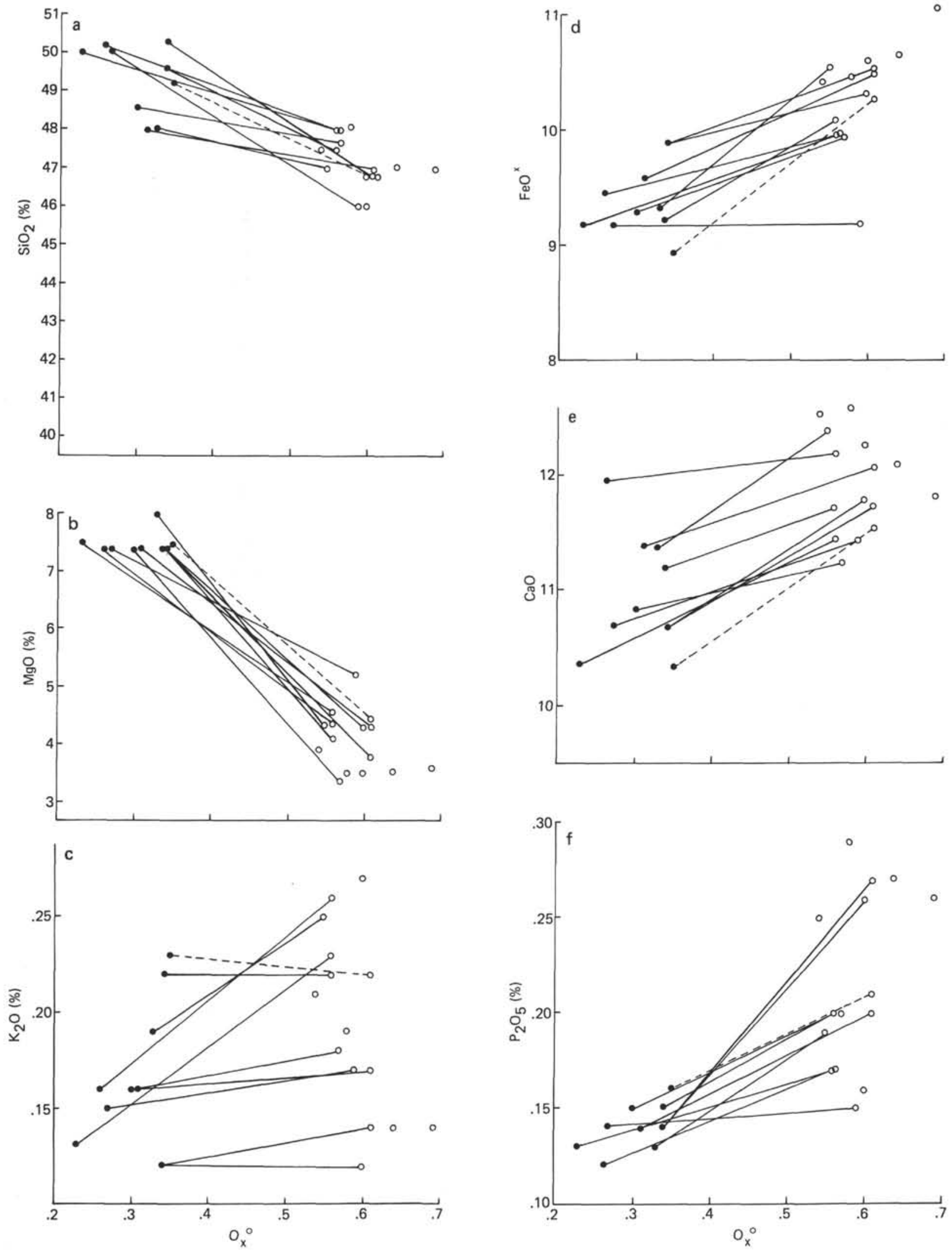

Figure 4. Bulk chemistry variations with alteration: weight oxides $\%$ vs. $O_{x}^{O}$. Note: $0=$ brown samples from Units 1 and 2. = gray samples from Units 1 and $2 . \bullet=$ green samples from Unit $5 .-1-=$ pairs of contiguous gray and brown samples. --_- = pairs of samples which do not come from the same core fragment. 

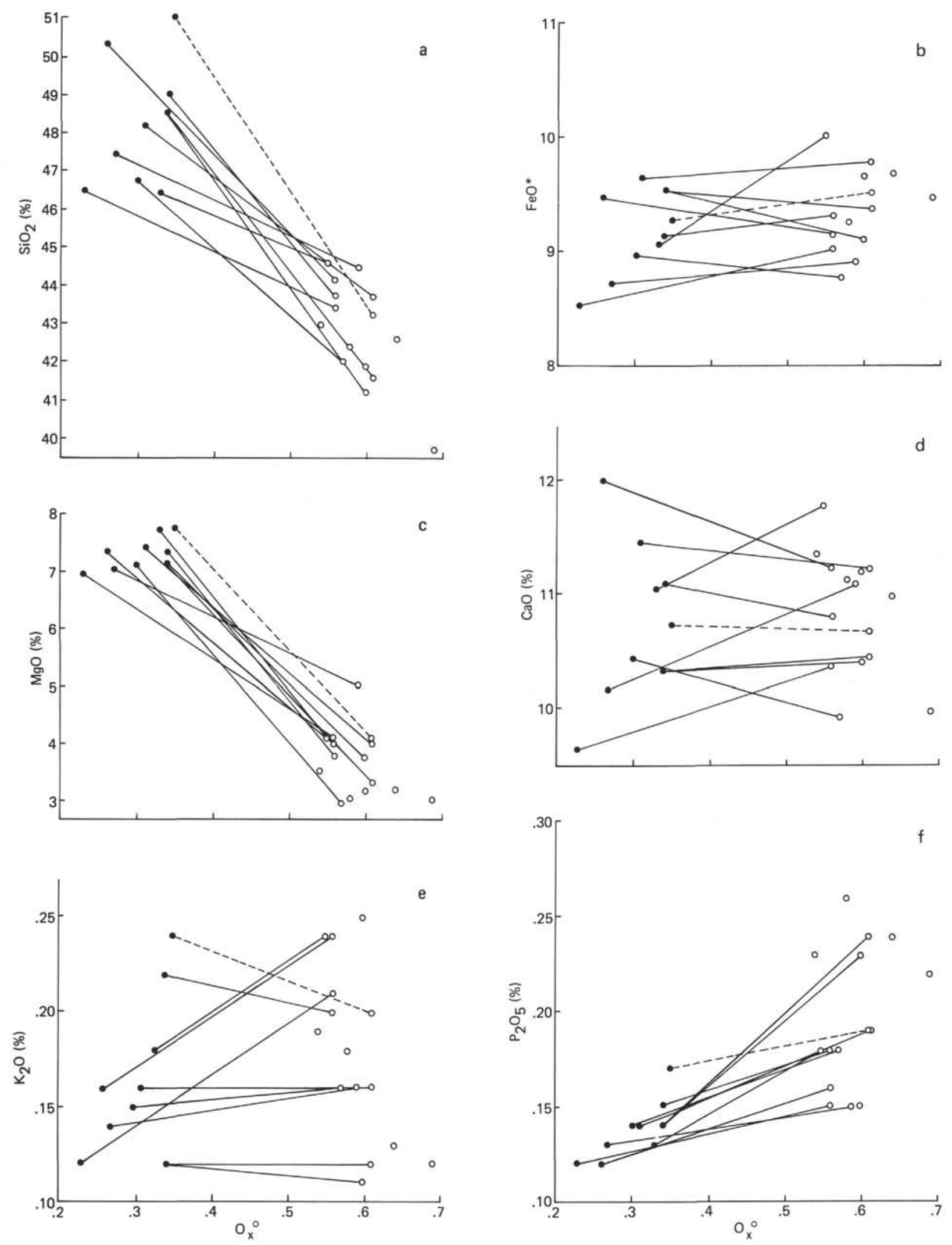

Figure 5. Bulk chemistry variations with alteration: weight oxides \% normalized with respect to $\mathrm{Al}_{2} \mathrm{O}_{3}$ vs. $\mathrm{O}_{x}^{O}$. 
magnesium because of the alteration (Figure $2 \mathrm{~b}$ ). The $\mathrm{MgO}$ content decreases from an average 7.8 per cent (calculated on $77 \mathrm{MgO}$ analyses by other contributors to this volume) in the gray rocks, to an average 4.1 per cent (calculated on 15 of our analyses) in the brown ones. This is a decrease by almost a factor of 2 .

2) Silica is also lost during the alteration, but in a much lesser proportion than magnesium. $\mathrm{SiO}_{2}$ percentages range from 50.2 to 48.0 in the gray samples, and from 48.1 to 46.0 in the brown ones (Figure 2a). Although the difference is small, there is practically no overlap between the ranges of $\mathrm{SiO}_{2}$ contents of the gray and brown zone samples. The precision and reliability of the gravimetric method is indispensable in revealing such small changes.

3) When one compares the manganese contents of the various pairs of gray and brown samples (Figure $2 c$ ), there appears to be a tendency toward a decrease in manganese with alteration in five pairs of samples. On the other hand, the $\mathrm{MnO}$ weight percentages have increased in four samples. This variability of the trends of manganese content changes could be explained by the petrographic observation that the distribution of the Mn-Fe oxides varies very much from one sample to another. However, one also must take into consideration that the range of $\mathrm{MnO}$ weight percentages of our brown samples completely overlaps that of the " fresh" rocks as reported by the various contributors to this volume. Therefore, one can conclude that at least part of the observed discrepancy between the $\mathrm{MnO}$ contents variations is due to the imprecision of the analytical methods used on rocks with such low manganese contents.

4) If one considers Figures 3 and 4, where the total iron, aluminum, titanium, sodium, and calcium weight oxides contents are plotted against the $\mathrm{H}_{2} \mathrm{O}^{+}$contents, or the oxidation ratios, one would conclude to an increase of these elements in the brown samples. But these changes are only relative because they are not observed in the graphs where the normalized weight percentages of the same oxides are plotted against the oxidation ratios (e.g., Figure 5). This means that the apparent increase in the brown samples of FeO*, $\mathrm{Al}_{2} \mathrm{O}_{3}, \mathrm{TiO}_{2}, \mathrm{CaO}$, and $\mathrm{Na}_{2} \mathrm{O}$ concentrations actually are due to the losses in $\mathrm{MgO}$ and $\mathrm{SiO}_{2}$. If $\mathrm{Al}_{2} \mathrm{O}_{3}$ is assumed to have been immobile, then the densities of the brown zones are on average about 8 per cent less than the densities of the gray zones.

5) The variations of the potassium content with alteration (Figures $2 \mathrm{~d}$ and $4 \mathrm{c}$ ) seem to be much more irregular than those of the other oxides even when normalized values are used (Figure 5e). The $\mathrm{K}_{2} \mathrm{O}$ weight percentage has a tendency to increase in the brown samples, and remains constant in two pairs. One must first notice that the range of $\mathrm{K}_{2} \mathrm{O}$ contents in the "fresh"' rocks analyzed by the various contributors to this volume, is one of the largest of all the elemental ranges of the lavas from Unit 1 that we have computed so far. Such a large discrepancy reflects the poor precision and reproducibility of the various methods used by the various laboratories, i.e., X-ray fluorescence spectrometry at NASA and by Sato et al. (this volume) and electron microprobe technique on natural glasses by Robinson and by Sato et al. (this volume). We have analyzed potassium by atomic absorption using solutions which were "spiked" with cesium as an ionization control buffer. It is probably one of the best methods available now for analyzing potassium in rocks with such small $\mathrm{K}_{2} \mathrm{O}$ contents. Our range of $\mathrm{K}_{2} \mathrm{O}$ contents $(0.13$ to 0.30$)$ for the gray rocks is smaller than those reported in this volume by the other laboratories, except where the electron microprobe was used. As stated before, the "black fronts," which contain abundant Fe-K-rich clay minerals, may have considerably higher $\mathrm{K}$-contents than either the gray or brown samples.

6) The $\mathrm{P}_{2} \mathrm{O}_{5}$ contents of brown zone samples are much higher than those of gray basalts, or of fresh glasses. Phosphorus has apparently been added during the strong oxidation stage of alteration and may, in fact, be contained in the abundant ferric hydroxides that have replaced olivine in the brown zones.

Limited analyses from Units 3 and 5 (Table 6) show that in those units also, strong oxidation is accompanied by hydration and carbonation. The $\mathrm{K}_{2} \mathrm{O}$ contents of all six samples are similar $(0.22-0.26 \%)$, and equal to the upper range encountered in Unit 1 . MgO contents in the most altered samples from both units are not greatly diminished although a slight decrease is observed in Unit $3 . \mathrm{P}_{2} \mathrm{O}_{5}$ contents of strongly oxidized samples are fairly high, suggesting that phosphorus has been added, as in the Unit 1 pillows.

We have not analyzed any samples from the porphyritic pillow sequence (Unit 4), but a shipboard XRF analysis of a brown sample (19-1, 4-6 cm[1]) suggests that the Unit 4 pillows have reacted in the same way as the Unit 1 pillows reported here.

\section{CONCLUSIONS}

We have conducted a detailed study of the mineralogical and chemical changes which took place within the last 13 $\mathrm{m}$.y. in the superficial portion of the oceanic crust with low temperature submarine alterations.

The mid-oceanic ridge pillow basalts of Units 1 and 2, and probably also 4 , forming the uppermost 200 meters of the oceanic crust at Hole $396 \mathrm{~B}$, have behaved in a relatively uniform manner, with respect to alteration. The pillow basalts have been subjected to (at least) two major stages of low temperature alteration: (1) an early slight oxidation and hydration which mainly affected the opaque Fe-Ti oxide phase in all of the studied samples; (2) a later stronger oxidation localized near cracks and other exposed surfaces which principally affected the olivine, but also the opaque phase.

The above grouping, of course, does not reflect the full range of alteration effects observed in these rocks, but it does represent two distinct major steps in the re-equilibration of the basalt to conditions on the sea floor.

A narrow ( 2 to $3 \mathrm{~mm}$ wide) "frontal"' zone, which marks the limit of the second-stage alteration, may or may not be simply transitional between the gray and brown rock on either side. Unfortunately, the "frontal" zones we encountered were too thin to be sampled for bulk properties measurements.

The first stage oxidation and hydration of the non-glassy part of the pillow basalts were accompanied by the following changes: 
1) The finer, magmatic titanomagnetite (from 0.5 to 5 $\mu \mathrm{m})$ has been severely oxidized, probably to titanomaghemite. This replacement affects the magnetic properties of the basalts such as the saturation magnetization and the Curie temperature (see Honnorez et al., this volume). The larger opaque phase (up to $40 \mu \mathrm{m}$ ) is only partly altered, at the rim.

2) The bulk rock oxidation ratio $\left(\mathrm{O}_{x}^{0}\right)$ derived from the chemical analyses has increased from a theoretical value of less than 0.14 (corresponding to a $1.5 \%$ maximum $\mathrm{Fe}_{2} \mathrm{O}_{3}$ content) to an average measured value of 0.31 (actual range from 0.24 to 0.35 ).

3) Smectite, calcite, or an unidentified orange secondary product (optically amorphous but no X-ray diffraction available) are observed as fillings of some miarolitic voids.

4) The $\mathrm{K}_{2} \mathrm{O}$ content has increased from 0.12 per cent (average of 31 microprobe analyses of fresh glasses by Robinson and by Sato et al., this volume) to 0.18 per cent. This excess in $\mathrm{K}$ is probably contained by the above-mentioned authigenic phases.

5) Occasionally, olivine has been partly replaced by smectite, but this has apparently not affected the bulk properties of the rock. It is remarkable that, besides the opaque phase, the magmatic minerals seem generally to have been unaffected and that the hand specimens do not display obvious signs of this first alteration stage.

The second-stage oxidation and hydration are characterized by an abrupt color change of the hand specimens from gray to brown across a 2 to $3 \mathrm{~mm}$-wide boundary. This color change suggests sharp chemical gradients and corresponds to the following mineralogical and chemical changes:

1) The olivine from the groundmass breaks down and completely disappears from whole-rock X-ray diffraction patterns. The olivine microphenocrysts $\left(\mathrm{O}_{*}^{0}\right)$ are replaced predominantly by ferric oxides.

2) The bulk rock oxidation ratio $\left(\mathrm{O}_{\mathrm{x}}^{0}\right)$ increases to an average value of 0.60 (actual range from 0.54 to 0.69 ) in the brown rocks. This is probably related to the oxidation of the olivine in the silicate matrix.

3) The titanomaghemite has started to break down and become lost. This observation corresponds to a marked decrease in the saturation magnetization.

4) Both $\mathrm{SiO}_{2}$ and $\mathrm{MgO}$ contents decrease, the latter by almost 50 per cent. Co and $\mathrm{Ni}$ have been partially lost with the $\mathrm{Mg}$, while $\mathrm{P}_{2} \mathrm{O}_{5}$ has been gained, possibly in the ferric hydroxides which have replaced olivine. All of the other elements remain practically unaffected; their concentrations are passively increased in the brown rocks.

5) Plagioclase is exceptionally (and then only partly) replaced by smectites and/or calcite; this replacement is never quantitatively important. Clinopyroxene appears to have remained unaffected. The cavities, which include vesicles and fissures, have been filled with the following sequence of secondary minerals: smectites and/or unidentified clay minerals, Fe-Mn oxides (both Fe-rich and Mn-rich), phillipsite (possibly $\mathrm{Na}>\mathrm{K}$ ), and calcite $(\mathrm{Mg}$ $2-8$ ). The common botryoidal or euhedral habits of these authigenic minerals suggest that they were deposited, from solutions, in pre-existing voids and not as replacement of magmatic phases such as an intersertal glassy matrix. The elements needed for precipitation of these authigenic minerals may have been derived from the alteration of the adjacent basalts, nearby glasses, and/or from seawater.

The glassy matrix of the variolitic zones of the pillow lavas, and the glass rims of the pillows have been palagonitized along fissures, i.e., the basaltic glass has been oxidized and hydrated, and smectites have coated the broken glass surfaces and precipitated in the fissures along with phillipsite, calcite, and $\mathrm{Fe}-\mathrm{Mn}$ oxides.

The massive basalt of Unit 3 has reacted in a generally similar way as the pillow basalts, but with several differences, including:

1) Color zonation is not as well defined because the strongly oxidized zones (where olivine has been destroyed) are brownish gray in appearance. This may be due in part to the grain size of the olivine, but may also be related to the observation that the replacement of olivine tends to be a smectite, or smectite hydrous oxide mixture in the massive basalt, rather than a relatively pure hydrous oxide as in the pillow basalts. In general, it appears that smectites are more abundant in the strongly altered zones of the massive basalts than they are in the brown zones of the pillow basalts.

2) Although the altered zones in Core 15 have been strongly oxidized and hydrated, and olivine destroyed, $\mathrm{MgO}$ has decreased only slightly, having been retained by the smectites.

3) Aragonite is present in vugs in the most altered parts of Unit 3, while phillipsite has not been observed. (The reverse is true of the pillow basalts.)

4) Titanomagnetite does not appear to have been as strongly affected by alteration in Unit 3 as it has been in the pillow basalts.

The samples from Core 23 (Unit 5) that were analyzed are all strongly oxidized and hydrated, and olivine has been destroyed. As in Unit 3, $\mathrm{MgO}$ and $\mathrm{SiO}_{2}$ have apparently been retained.

In summary, all of the basalts from Hole 396B that we have studied have been altered (but none to an extreme degree). We conclude that the alteration process (or processes) which affected most of the basalts of Hole 396B that we have studied took place at a relatively low temperature range. The sequence of the various authigenic minerals is probably related to either chemical or temperature variations through time of the mineralizing solutions in the voids and cracks, or possibly to both simultaneously. The association smectite-phillipsite with $\mathrm{Mg} \mathrm{2-8} \mathrm{calcite} \mathrm{and} \mathrm{poorly} \mathrm{crystallized} \mathrm{Fe-Mn} \mathrm{oxides} \mathrm{is}$ representative of low temperature alteration processes. We cannot be more accurate at this stage of our study, but the general lack of mineral characteristic of the greenschist facies, and of the higher temperature zeolites (e.g., wairakite or laumontite) which are characteristic of the zeolite facies lead us to think that no temperature higher than about $150^{\circ} \mathrm{C}$ was sustained for a long period of time. One cannot exclude, however, the possibility that some of the secondary minerals are not the unstable products of brief deuteric events at higher temperature. Both in the pillow and massive basalts, the possibility of deuteric alteration is suggested by the presence of miarolitic voids with overly developed protruding titanomagnetite and pyroxene 
crystals, the occasional marginal overgrowths of hematite on the titanomagnetite, and of fibrous aggregates on the pyroxene. However, these possibly deuteric phases are quantitatively unimportant when compared with the lower temperature authigenic minerals.

The major chemical fluxes during alteration of the crystalline interior of the pillow basalts have been controlled strongly by the stabilities of the individual igneous minerals. Whereas olivine was eventually altered, the plagioclase and pyroxene have been essentially unaffected. The massive basalt (Unit 3) has reacted somewhat differently from the pillow basalts above and below it, suggesting that texture and/or structure also play an important role in controlling the results of alteration.

\section{ACKNOWLEDGMENT}

We want to thank Dr. Sheldon Sommer for his help during the electron microprobe analyses. We thank Dr. O Joensuu and Mrs. M. Riera for carrying out the chemical analyses. This research was supported by National Science Foundation under Grant No. OCE76-82154.

\section{REFERENCES}

Ade-Hall, J.M., Fink, L.K., and Johnson, H.P., 1976. Petrography of opaque minerals, Leg 34. In Hart, S.R., Yeats, R.S., et al., Initial Reports of the Deep Sea Drilling Project, v. 34: Washington (U.S. Government Printing Office), p. 349-362.

Bass, M.N., 1974. Secondary minerals in basalt, DSDP Leg 34 (Abst.), Geol. Soc. Am. Ann. Mtg. (Miami Beach) Abst. w/Prog., v. 6 , p. 646.

, 1975. Secondary minerals in oceanic basalts, Carnegie Inst. Year Book 74, p. 234-240.

, 1976. Secondary minerals in oceanic basalt, with special reference to Leg 34, DSDP. In Hart, S.R., Yeats, R.S., et al., Initial Reports of the Deep Sea Drilling Project, v. 34: Washington (U.S. Government Printing Office), p. 393-432.

Chapman, H.J., Spooner, E.T.C., and Smewing, J.D., 1975. ${ }^{87} \mathrm{Sr}$ enrichment of ophiolitic rocks from Troodos, Cyprus indicates sea water interaction (Abst.) EOS-Trans. Am. Geophys. Union, v. 56, p. 1074 .
Hart, R., 1970. Chemical exchange between seawater and deep ocean basalts, Earth Planet. Sci. Lett., v. 9, p. 269-279.

,1973a. Geochemical and geophysical implications of the reaction between seawater and the oceanic crust, Nature, v. 243, p. $76-78$.

, 1973b. A model for chemical exchange in the basalt-seawater system of oceanic Layer II, Canadian J. Earth Sci., v. 10 , p. $799-816$.

Hart, S.R., 1969. K, Rb, Cs contents and K/Rb, K/Cs ratios of fresh and altered submarine basalts, Earth Planet. Sci. Lett., v. 6, p. 295-303.

, 1971. K, Rb, Cs, Sr, and Ba contents and $\mathrm{Sr}$ isotope ratios of ocean floor basalts. Phil. Trans. Roy. Soc. London, v. A268, p. 473-587.

Hekinian, R., 1971. Chemical and mineralogical differences between abyssal hill basalts and ridge tholeiites in the eastern Pacific Ocean, Marine Geol., v. 11, p. 77-91.

Lister, C.R.B., 1975. Rapid evolution of geothermal systems in new ocean crust predicts mineral output mainly near ridge crests (Abst.), EOS-Trans. Am. Geophys. Union, v. 56, p. 1074.

Mathews, D.C., 1971. Altered basalts from Swallow Bank, an abyssal hill in the NE Atlantic, and from a nearby seamount, Phil. Trans. Roy. Soc. London, v. A268, p. 551-574.

Miyashiro, A., Shido, F., and Ewing, M., 1969. Diversity and origin of abyssal tholeiite from the Mid-Atlantic Ridge near $24^{\circ}$ and $30^{\circ}$ North, latitude, Contrib. Mineral. Petrol., v. 23, p. 38-52.

, 1971. Metamorphism in the Mid-Atlantic Ridge near $24^{\circ}$ and $30^{\circ}$ N., Phil. Trans. Roy. Soc. London, v. A268, p. 589-604.

Miyashiro, A., 1973. Metamorphism and metamorphic belts: New York (J. Wiley and Sons).

Shido, F., Miyashiro, A., and Ewing, M., 1974. Compositional variation in pillow lavas from the Mid-Atlantic Ridge, Marine Geol., v. 16, p. 177-190.

Spooner, E.T.C. and Fyfe, W.S., 1973. Sub-sea-floor metamorphism, heat, and mass transfer, Contrib. Mineral. Petrol., v. 42, p. 287-304.

Thompson, G., 1973. A geochemical study of the low-temperature interaction of seawater and oceanic igneous rocks, EOS-Trans. Am. Geophys. Union, v. 54, p. 1015-1019.

Wolery, T.J. and Sleep, N.H., 1975. Hydrothermal reaction at mid-ocean ridges: some implications and constraints (Abst.), EOS-Trans. Am. Geophys. Union, v. 56, p. 1073. 



\section{PLATE 1}

Textures From Units 1, 2, and 3 (all same scale, plane transmitted light)

Figure 1 Glass (light) with coalescing varioles; varioles are skeletal-radial growths of pyroxene, olivine, and plagioclase? often with plagioclase microlite nuclei. Sample 8-1-13, 118-120 cm (13).

Figure 2 Almost variolitic. Subradial intergrowths of plagioclase, pyroxene, and olivine (no glass is seen in this or any of the following). Sample 8-1-13, 118-120 $\mathrm{cm}$ (13), approx. $1 \mathrm{~cm}$ from Figure 1.

Figure 3 Subvariolitic. Scattered clots of suboriented plagioclase needles with fine intergrowths of plagioclase, pyroxene, and olivine, and few skeletal olivine grains (olivine phenocryst in lower right). Sample 7-2-5, 47-49 cm (5).

Figure 4 Subvariolitic. Sheaf-like bundles of plagioclase needles with fine intergrowths of pyroxene, plagioclase? and olivine? and scattered skeletal olivine grains. Sample 12-1-1, 9-11 cm (1).

Figure 5 Intersertal. Plagioclase microlites and olivine granules with fine intergrowths of pyroxene, plagioclase? and olivine? Sample 7-1-12, 145-147 cm (12).

Figure 6 Coarse-grained intersertal. Large plagioclase microlites (lathes) with olivine granules and skeletal pyroxene (olivine is mostly replaced by dark brown material). Sample 15-3-3A, 90-93 cm (3A). 
PLATE 1
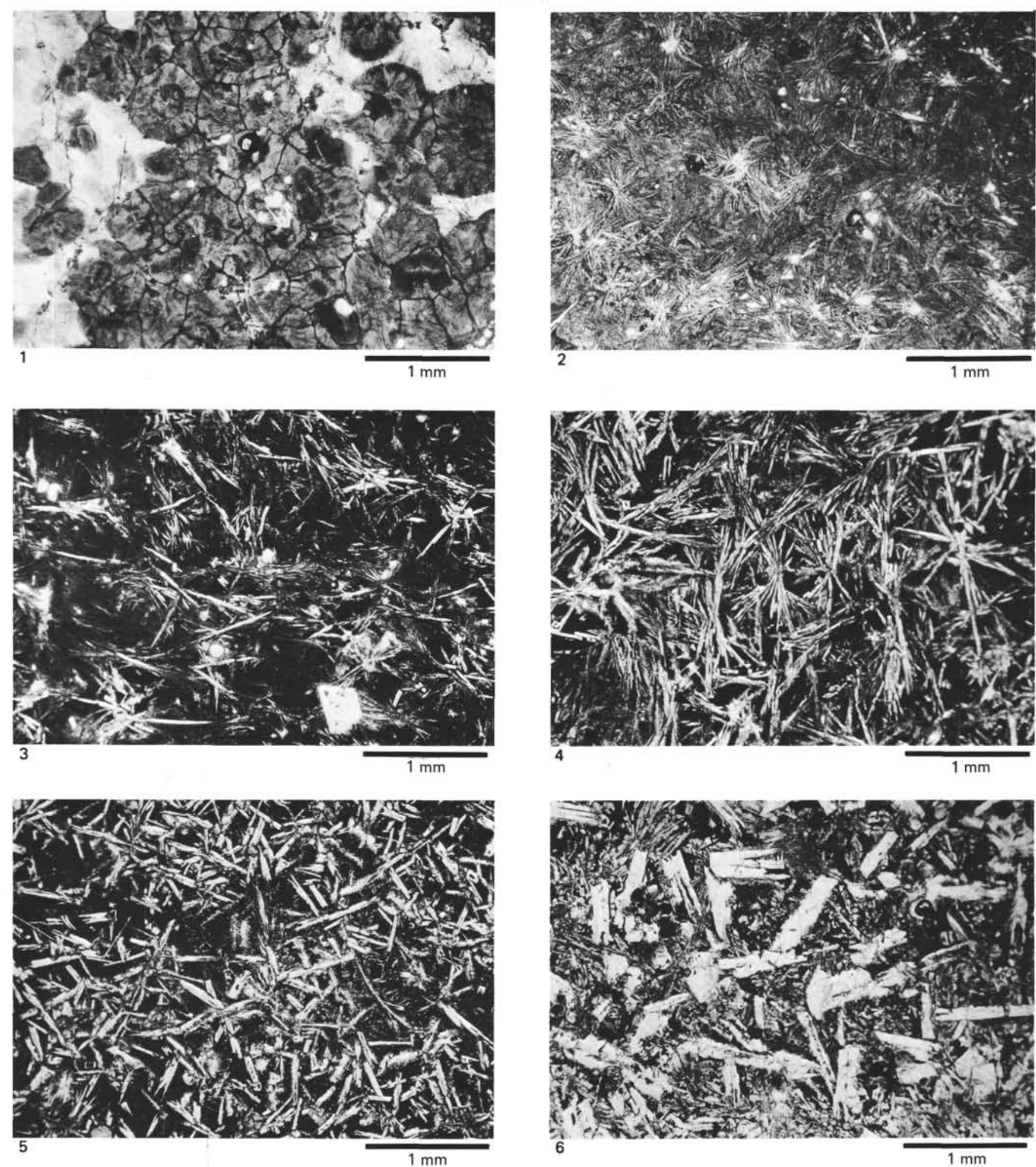
PLATE 2

Hand Specimens

Figure 1

Figure 2

Figure 3
Color zoning in Units 1 and 2. Typical zonation patterns controlled by veins and exposed surfaces (see text). Samples 7-2, 96-98 cm (9) and 5-2, 113-117 cm (12) — "light front'"; Sample 4-2, 10-13 cm (2) "black front"' (and light front?); Sample 8-2, 57-61 $\mathrm{cm}(6 \mathrm{~A})$ - another type not yet studied.

Vugs in "Cooling Unit" 3. Irregular large vugs filled mainly with calcite (light) or clays and Fe-Mn oxides (dark). See text for discussion.

Broad color zoning in Unit 4. Typical broad, poorly defined zonation controlled by veins and exposed surfaces. Sample 16-1, 3-8 cm (1) - two brown bands alongside central gray area; Sample 17-1, $88-92 \mathrm{~cm}(8 \mathrm{~B})$ - all brown with vein (filled with clay, Fe-Mn oxides, and phillipsite); Sample 21-1, $18-29 \mathrm{~cm} \mathrm{(3)} \mathrm{-} \mathrm{dark} \mathrm{gray} \mathrm{(extreme} \mathrm{left)} \mathrm{to} \mathrm{brown}$ (right). The upper right edge is a very altered glassy area. 


\section{PLATE 2}



\section{PLATE 3}

Veins

Figures 1, 2 1. (plane light)

2. ( $\times$ polars $)$

Concentrically zoned vein made up by: (1) Lining of birefringent smectite, (2) discontinuous bulbous $\mathrm{Fe}-\mathrm{Mn}$ oxide layer, (3) radial clusters of phillipsite prism (nearly isotropic), (4) granular calcite with dispersed phillipsite. An angular basalt fragment in the vein is coated in the same way as the vein walls. Sample 7-2-4, 34-36 cm (4).

Figure 3 ( $\times$ polars) reopened vein (see text)

A thin layer of fibrous calcite (second phase) runs along one side of a concentrically zoned vein (first phase). The first phase calcite is clean and bulbous (wavy extinction) in contrast to the calcite in the vein shown in Figures 1 and 2. One vein wall is missing in the thin section (upper part of photograph). Sample 7-2-9, 96-98 cm (9).

Figures 4,5 4. (plane light)

5. ( $\times$ polars $)$

"Geopetal" surface in a vertical vein. The lower fill is "dirty" phillipsite (isotropic). The upper part is zoned with small amounts of clay and Fe-Mn oxide (not visible) and euhedral phillipsite on the walls, and granular calcite. The thin calcite tongue extending downward seems to be related to a reopening. A vertical band of phillipsite "suspended" in the calcite has been pulled off the wall on the right, perhaps by the same reopening. Calcite replaced parts of plagioclase phenocrysts near the vein. Sample 20-2, $130-135 \mathrm{~cm}(9 \mathrm{~F})$. 


\section{PLATE 3}



\section{PLATE 4 \\ Vug Fillings \\ (all plane polarized light)}

Figure $1 \quad$ Filled miarolitic voids. Exceptionally large pyroxene grains (high relief) are found only in vugs. In the surrounding rock they are submicroscopic. The fill is olive-green clay (yellow in thin section). Sample 8-2, $17-19 \mathrm{~cm}$ (2) ("black front").

Figure 2 Miarolitic void and vesicle, both filled by the same clays. The rims are olive-green $\mathrm{Fe}>\mathrm{Mg}$ botryoidal clay, and the centers are white $\mathrm{Mg}>\mathrm{Fe}$ smectite. The shadows are caused by the sloping contact between the two. Sample 8-2, 17-19 cm (2) ("'black front").

Figure 3 These vugs have the same olive-green rims as in Figure 16, but the cores are Fe-Mn oxide. Sample 8-2, 17-19 cm ("black front').

Figure $4 \quad$ Multiple vesicle fill. Fill consists of (1) thin yellow-green lining and (2) white translucent band (smectites), and (3) a core of Fe-Mn oxide. Sample 7-2, 96-98 cm (9).

Figure $5 \quad$ Large dark vug lining from the "Cooling Unit" 3. Muddy green clay (gray) with included brown-black Mn-rich streaks and patches is overlain by remnants of thin purple coating and nodular Mn oxide (black). The orthogonal pattern in the white (empty) center is caused by probe tracks in epoxy. Sample 15-3, 90-93 $\mathrm{cm}(3 \mathrm{~A})$.

Figure 6 Yellow fibrous smectite overgrown on pyroxene at the edge of a calcite-filled vug. Sample 15-3, 90-93 $\mathrm{cm}(3 \mathrm{~A})$. 
PLATE 4

PLATE 5

Opaque Phases

(The bar in each figure is $10 \mu \mathrm{m}$ long. All figures are in reflected light, oil immersion.)

Figure 1 Cluster of homogeneous euhedral magnetite; small white grains are skeletal magnetite. Lath-shape grain is probably ilmenite.

Figure 2 Large skeletal growth of magnetite with medium gray chrome-spinel(?) core. Fine anhedral to skeletal magnetite and two small spherules of sulfide.

Figure 3 Euhedral homogeneous magnetite (medium gray) with a partial fringe and adjacent needle of hematite (white).

Figure 4 Skeletal growth of magnetite and also anhedral grains (light gray) with adjacent sulfide spherules (white). Lath-shape crystals of probable ilmenite(?). 
PLATE 5
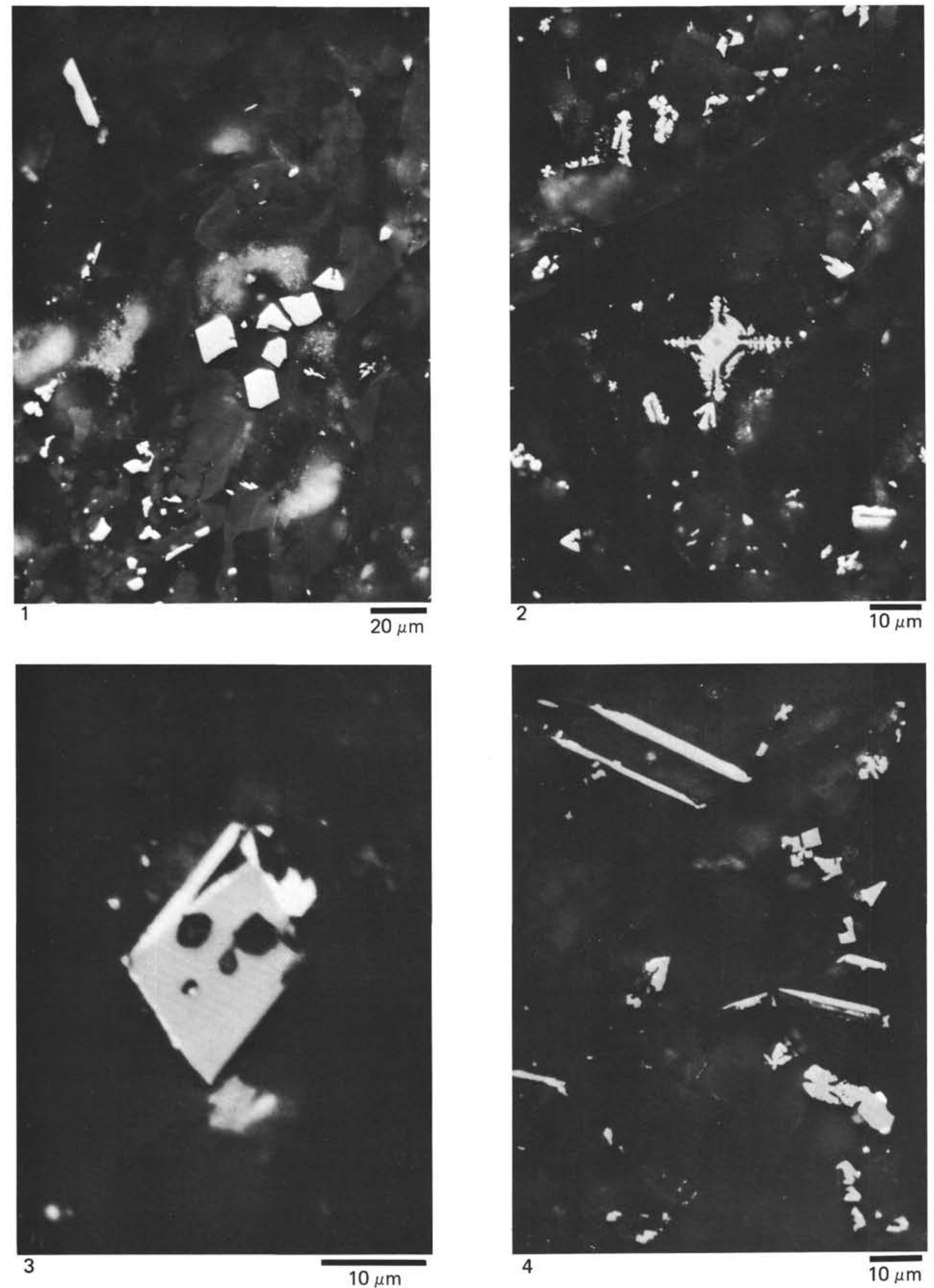